\title{
Determinants of Personal Protective Equipment (PPE) use in UK motorcyclists: exploratory research applying an extended Theory of Planned Behaviour
}

Emma Norris ${ }^{1}$ and Lynn Myers ${ }^{1 *}$

1 School of Social Sciences, Brunel University, UK

Word count (exc. figures/tables): 4976

${ }^{*}$ Requests for reprints should be addressed to Prof. Lynn Myers, School of Social Sciences, Brunel University, Uxbridge, Middlesex, UB8 3PH, UK (telephone: +44 1895 265879., email: Iynn.myers@brunel.ac.uk). 


\section{Abstract}

Despite evident protective value of motorcycle personal protective equipment (PPE), no research has assessed considerations behind its uptake in UK riders. A cross-sectional online questionnaire design was employed, with riders $(n=268)$ recruited from online motorcycle forums. Principal component analysis found four PPE behavioural outcomes. Theoretical factors of intentions, attitudes, injunctive and descriptive subjective norms, risk perceptions, anticipated regret, benefits and habit were also identified for further analysis. High motorcycle jacket, trousers and boots wear, middling highvisibility wear and low non-Personal Protective Equipment wear were found. Greater intentions, anticipated regret and perceived benefits were significantly associated with increased motorcycle jacket, trousers and boots wear, with habit presence and scooter use significantly associated with increased high-visibility wear. Lower intentions, anticipated regret and risk perceptions, being female, not holding a car licence and urban riding were significantly associated with increased non-PPE wear. A need for freedom of choice and mixed attitudes towards PPE use were evident in additional comments. PPE determinants in this sample provide a 
preliminary basis for future uptake interventions. Larger scale and qualitative research is needed to further investigate relevant constructs.

\section{Keywords}

Personal Protective Equipment, motorcyclists, Theory of

Reasoned Action, habit, anticipated regret 


\subsection{Introduction}

Motorcyclists account for $1 \%$ of UK road users but are $57 \%$ more likely to be killed or seriously injured (KSI) than car drivers (Department for Transport (DfT), 2012; Think! 2011).

Currently, British or European Economic Area Standard approved helmets are the only mandatory protection required by UK riders (The Secretary of State for the Environment, Transport and the Regions, 1998). Although these hold wellvalidated protective value (Liu et al. 2008), much un-legislated but formally standardised Personal Protective Equipment (PPE) is additionally available (Think! 2010). Use of protective jackets and trousers in particular make riders significantly less likely to be admitted to hospital following a crash (De Rome et al. 2011a; Think!, 2010). Although PPE often cannot prevent major injuries in high impact crashes; it can reduce torn ligaments, broken bones and gravel rash following minor crashes (De Rome \& Stanford, 2006; De Rome et al. 2004). Additionally, the use of bright and fluorescent clothing can help increase rider conspicuity: aiding crash prevention (Wells et al. 2004).

Despite the evident protective value of motorcycle PPE, there is currently a lack of research surrounding its uptake and related reasoning. The Theory of Planned Behaviour (TPB; Ajzen, 1991; Fishbein \& Ajzen, 2010) has been used to predict a vast array of health behaviours (Armitage \& Connor, 2001), including related motorcycle helmet use (Ali et al. 2011).

An extension of the Theory of Reasoned Action (TRA; Fishbein and Azjen, 1975; Figure 1); both theories propose the primary antecedent of behaviour to be the individual's intention to perform the action. Both models describe intentions as partly determined by attitudes (positive or negative evaluations towards the 
behaviour) and subjective norms (perceived social pressure from significant others towards the behaviour). The additional TPB component of perceived behavioural control (PBC; perceived ease or difficulty of behaviour) is suggested to hold both direct and indirect influence on behavioural outcomes (Ajzen \& Fishbein, 2005; Figure 2).

Significant explanatory value in TPB is frequently found by adding additional constructs (Conner \& Armitage, 1998), with this evident in related research investigating drink-driving (Chan et al. 2010; Rivis et al. 2011) and speeding behaviours (Elliot, 2010; Elliot \& Armitage, 2009). This study employed an extended TPB to capture maximal potential determinants of motorcycle PPE use.

Subjective norm was expanded into injunctive subjective norm (ISN; representing the original component; Ajzen, 1991) and descriptive subjective norm (DSN; perceived behaviour of significant others; Cialdini et al. 1991) to improve explanatory value (Rivis \& Sheeran, 2003). PBC was expanded with self-efficacy (perceived success in achieving target behaviour; Schwarzer, 1992): found to hold double the explanatory value of PBC (Armitage \& Connor, 2001). Additionally, attitude measures were expanded with typically highly-predictive benefit and barrier items (Carpenter, 2010) to fully capture PPE opinions identified during preliminary belief elicitation.

TPB is argued to hold an overly motivational-focus (Conner \& Armitage, 1998). Hence, examination of habits was added here to assess the effect of past behaviour on PPE use. Describing behaviours arising as routine responses to situational cues (Verplanken \& Aarts, 1999; Verplanken \& Orbell, 2003), habits may exist in riders using PPE when riding regularly.

To further examine affective processes behind PPE use, anticipated regret (AR) was also used. This describes negative emotions experienced if an individual 
perceives they could prevent a harmful future event (Abraham \& Sheeran, 2003).

AR adds around $7 \%$ of explanatory value to standard TPB factors (Sandberg \& Connor, 2008) and has been successfully used to examine PPE-related speeding behaviour (Conner et al. 2007; Parker et al. 1996).

Risk perceptions of dangerous situations surrounding non-PPE use were also explored (Kobbeltvedt \& Wolff, 2009). Response efficacy (RE) items prompted individuals to consider the true protective value of motorcycle PPE (Germeni et al. 2009). "Risk as feelings" (RAF) items prompted consideration of emotional influences on PPE behaviour (Finucane et al. 2000a; Loewentstein et al. 2001). With males as the primary population of UK riders found to demonstrate less risk aversion than females (DfT 2010; Finucane et al. 2000b), exploration of motorcyclist-specific risk perceptions seems appropriate here.

Previous TPB research has examined predictors of unlegislated motorcycle helmet use (Ali et al. 2011) and safety wear in other vulnerable activities, including cycling (Ross et al. 2010; Rutter \& Vance, 2011), snow-sports (Cundy et al, 2010) and in-line skating (Deroch et al. 2009). In these contexts PPE usage is typically low, with users commonly found to possess more positive attitudes, repeated past behaviour and fewer past accidents than non-users (O"Callaghan \& Nausbaum, 2006). Selected UK research has assessed prevalence (Sexton et al. 2004) and general attitudes towards PPE (Christmas et al. 2009), both as part of wider motorcycling research commissioned by the Department for Transport. However, only limited Australian research has attempted to apply psychological theory in examining motorcycle PPE determinants (De Rome et al, 2011b). Original TPB factors of negative attitudes and low ISN, with demographic factors of lower age and scooter riding were found to determine non-PPE use (De Rome et al, 2011b). Although providing tentative evidence of perceptions in hotter climates, no previous research has examined psychological motorcycle PPE 
determinants in the UK or using an extended theoretical model.

This study aimed to investigate psychological associations with UK motorcycle PPE and non-PPE use, using an extended TPB and belief elicitation. With this preliminary research seeking to explore relevant determinants; only brief, general hypotheses based on aforementioned theoretical and PPE research were formulated:

1) There will be differences in reported PPE use and perceptions between different riding demographics.

2) An extended TPB will explain significantly more PPE use than standard TPB alone. 


\section{Method}

\subsection{Design and Procedure}

A cross-sectional online questionnaire was designed to investigate psychological determinants of PPE use in UK motorcyclists. Informed consent was required at questionnaire onset following study approval by a London (UK) University Ethics Committee. A filter question ensured responders met the inclusion criteria of being UK residents: with British riders being the target demographic of this research.

\subsection{Participants}

Participants were recruited from March to May 2012 via various UK online motorcycle forums. Standardised invitation wording and a link to the developed SurveyMonkey questionnaire website were provided (www.motorcyclesafetywear.co.uk). A range of forums were selected to appeal to as broad a range of riders as possible: including general, scooter and female sites. A priori G-Power analysis (Faul et al. 2007) indicated a sample of 123 was required to detect a medium effect size in a regression analysis with a maximum of 11 predictor variables and with $80 \%$ power.

A total of 413 responses were received, with 23 respondents excluded for not meeting residency inclusion criteria. Responses with no usable outcome data or missing constructs were removed. Pairwise deletion of missing cases was then used to retain maximal data (Tabachnick \& Fidell, 2001). The final number of responses included in analysis was reduced to 268 (64.9\% of original total; Figure 3) following typical high rates of online questionnaire attrition (Fjeldsoe et al. 2009). 


\subsection{Measures}

Key demographics of gender, age, motorbike type and size were assessed at the study"s outset. Additional questions were provided after theoretical questions, assessing ethnicity, local area type, educational level, owned vehicle licences, motorcycle organisation membership and accident history.

Due to the novel nature of this research, no specific questionnaire existed to assess safety wear use in this sample. As such, constructs were identified for consideration through (i) examination of the few aforementioned related studies (ii) a literature review of health psychology models (iii) preliminary belief elicitation with three UK riders (Fishbein \& Ajzen, 2010). The resultant questionnaire consisted of eighty-four items measuring demographic information, use of PPE and theoretical constructs assessing its use. Constructs of the Theory of Planned Behaviour (TPB; Ajzen 1991) were extended with aforementioned additional constructs to examine determinants of PPE. All theoretical items were presented as 7-point Likert scales (Weinstein et al. 2007), with these counterbalanced throughout to prevent response order effects (Oppenheim, 2000).

\section{Intention}

Intention was assessed with seven items assessing likelihood of wearing PPE from definitely do to definitely do not in varying contexts, such as "I intend to wear full Personal Protective Equipment on a cold day".

\section{Attitudes}

Attitudes identified during pre-questionnaire literature review and belief elicitation (Ajzen \& Fishbein, 2005) were assessed with four semantic differentials, such as "Wearing full Personal Protective Equipment whilst riding is: unpleasant to pleasant". 


\section{Social norms}

Injunctive and descriptive social norms in relation to PPE were assessed with two items respectively. Responses indicated agreement from strongly agree to strongly disagree for items such as: "Riders I most respect wear full Personal Protective Equipment".

\section{$P B C$ and Self-efficacy}

Perceived behavioural control and self-efficacy of PPE use was assessed with three items in total, with responses indicating agreement from strongly agree to strongly disagree or no control to complete control. For example, one PBC item asked: "How much control do you have over whether or not you wear full motorcycle safety clothing whilst riding?"

\section{Benefits}

Benefits identified during pre-questionnaire belief elicitation were assessed in relation to PPE with four semantic differentials, such as "Full Personal Protective Equipment makes me feel: warm to cold".

\section{Anticipated regret}

Perceived anticipated regret of being injured as a result of not wearing PPE was assessed with three semantic differential items, such as "How would you feel if you were injured as a result of not wearing full motorcycle safety clothing?: worried to calm".

\section{Risk perceptions}

Perceptions of risk surrounding riding were assessed with two "risk as feelings" items (Loewenstein et al. 2001), with responses indicating agreement from strongly agree to strongly disagree. For example, "Without motorcycle safety clothing, I would feel that I would have a serious accident". 
Response efficacy

Perceived effectiveness of PPE at protecting against injury was assessed with two items; with responses indicating agreement from strongly agree to strongly disagree. For example: "Wearing full motorcycle safety clothing whilst riding would make me feel safer".

\section{Self-Report Habit Index (SRHI)}

The original SRHI (Verplanken \& Orbell, 2003) was used in this study to measure habit strength in motorcycle Personal Protective Equipment use. The scale has been found to hold high explanatory value, accounting for $65 \%$ of travel-related behaviours (Gardner et al. 2011). Responses are indicated on a 12 item, 7 point Likert from strongly agree to strongly disagree. A cut off score of 21 was used, with higher scores indicating habit presence (Lally et al. 2010).

\section{PPE use outcomes}

The primary outcome of PPE use was measured in a similar style to related research (De Rome et al, 2011b; Sexton et al. 2004). 5 point Likert scales were used with the phrasing "When riding in (summer/winter) conditions, how often do you...?". Distinction was drawn between the two diverse seasons to capture PPE use across variant riding conditions (De Rome et al, 2011b; DfT, 2009). Following examination of existing advice publications (Think! 2010; Think! 2011), 15 items for each season were provided, ranging from protective leather one-piece suits to no safety wear.

\section{Belief elicitation}

To extend the belief elicitation attained prior to questionnaire design (Fishbein \& Ajzen, 2010), participants were requested to provide additional PPE comments 
following all other questions.

\subsection{Data Analysis}

Principal Components Analysis (PCA) was used to explore the underlying structure of all variables in this sample, using SPSS Version 19 for Windows.

Direct Oblimin rotation was used to allow for inter-correlations among factors. The number of factors generated was not constrained to allow full exploration of this novel data. Pattern matrix values were used to examine unique contributions of items to factors, although structure matrix values are also reported (Graham et al. 2003). Factors with eigenvalues over 1.0 were selected (Kaiser, 1960), with only item factor loadings larger than 0.4 considered (Stevens, 1996).

Cronbach"s a was calculated to assess internal reliability of all identified constructs and the SRHI, with items deleted if improvements were possible (0.70.8: "acceptable", 0.8-0.9: "good", 0.9-1: "excellent" (Kilne, 1999)). Parametric group differences were assessed with t-tests or ANOVAs, with Mann Whitney $U$ or Kruskal Wallis tests used if data was not normally distributed.

Multiple regressions were performed for all PPE outcome variables, with dummy coding used for categorical variables such as age and bike size (Hardy, 1993). Initial forced entry regression of all independent variables identified statistically significant coefficients. Hierarchical regression analysis was then performed, excluding statistically redundant variables (Field, 2009). Intention was added first as the primary behavioural determinant in both TPB and TRA (Ajzen, 1991), followed by significantly predictive TRA factors. Significant demographics were then added to test Hypothesis 1 and additional theoretical variables added to test Hypothesis 2. Demographics were included in multiple regression analysis as TPB and associated models typically do not mediate the effects of demographic variables (Armitage et al. 2002). Examination of residual histograms and p-plots 
indicated normal distribution of regression errors (Field, 2009), with all regressions surpassing the recommended 10:1 participant-to-variable ratio (Oppenheim, 2000).

Content analysis was used to analyse additional comments. Statements were read and re-read, with margins annotated with emerging themes before being clustered into related concepts (Joffe \& Yardley, 2003). All comments were subject to inter-rater reliability by the project supervisor (LM). 


\section{Results}

\subsection{Assessing questionnaire factor structure}

Although summer and winter PPE were assessed separately, Spearman"s correlation coefficients found significant relationships between both outcome sets (Table 1). Subsequent PCA hence examined these outcomes collectively. Initial analysis identified ten outcome factors, clearly clustered into PPE and non-PPE groups. Separate analysis of these found three PPE factors and two non-PPE factors. PPE was further reduced to two factors due to highly skewed responses for leather suit wear: with $82.6 \%$ of respondents never wearing these across seasons.

This provided two PPE factors: "protective" PPE including five items assessing motorcycling jackets, trousers and boots (PPE1), and "preventative" PPE including four items assessing hi-visibility wear (PPE2). Two Non-PPE factors included four items assessing use of non-biking jeans and trainers (Non-PPE1), and five items assessing shorts, sandals and no safety wear (Non-PPE2) (Table 2). Scores for identified factors were calculated by summing the individual item scores and dividing this by the number of items in each scale. Significant correlations were found between PPE and Non-PPE scales respectively (Table 3). KS Lilliefors tests found no outcomes to be normally distributed $(p<0.001)$. Protective PPE (PPE1) held positive skewness and kurtosis towards PPE use, whereas both non-PPE scales were negatively skewed towards non-use.

Separate PCA for theoretical independent variables identified seven constructs to add to the pre-validated SRHI scale (Table 4). The TPB concept of PBC and related SE did not load well onto any factors, with both removed from further analysis (Trafimow et al. 2002). Hence, the model analysed and extended hereafter was the Theory of Reasoned Action (TRA). 
Although DSN items loaded well onto a scale with RE and RAF items, the items did not cumulatively hold face validity (Oppenheim, 2000). DSN was hence separated from the subsequently labelled "Risk Perceptions" factor, into its own scale to maintain clarity in further analysis (Table 4). Despite holding uncertain reliability, the benefits scale ( $a=0.64$; Table 5$)$ was maintained in subsequent analysis as related topics appeared frequently in both pre- and post-belief elicitation (Figure 4). Significant Spearman"s correlation coefficients were identified across identified constructs (Table 6). KS Lilliefors tests found risk perceptions, intentions, ISN and habits to all be positively skewed $(p<0.001)$. KMO statistics of over .6 for both independent and outcome variable PCA indicated good sampling adequacy (Hutcheson \& Sofroniou, 1999).

\subsection{Sample characteristics}

Of the two hundred and sixty eight included participants, $86.6 \%(n=232)$ were male with a mean group age of $30-39.89 .9 \%(n=241)$ rode a motorcycle as opposed to a scooter and $97.2 \%(n=246)$ identified themselves as white. With only 7 participants describing themselves as of black or asian ethnicities, this demographic data was removed from subsequent analysis to avoid biasing results (Field, 2009). Participants held a mean riding experience of 9.2 years, with $45.9 \%$ having three years or less. $68.6 \%(n=179)$ of participants reported holding full, unrestricted motorcycle licences, $74.8 \%(n=196)$ as holding car licences and $64.9 \%(n=170)$ as riding primarily in urban locations (Table 7$)$.

\subsection{PPE use}

Frequent reported wear of motorcycle trousers, jacket and boots was found in the sample (Mean=4.39 out of 5; PPE1, Table 8 ). $81.4 \%$ indicated often or always wearing these items, with wear significantly greater in motorcycle than scooter 
riders $(p<0.001)$. Middling usage was evident for high-visibility items (Mean=2.62; PPE2), with $19.4 \%$ indicating frequent wear.

Uncommon reported usage of non-motorcycle jeans and trainers was evident (Mean=1.79; Non-PPE1), with these items never worn by $42.5 \%$ of respondents. Wear was significantly greater in urban riders $(p<0.01)$ and those not holding a car licence $(p<0.001)$. Shorts, sandals and no safety wear (Mean=1.15; NonPPE2) were described as never worn by $79.5 \%$ of respondents, and were worn significantly more by women $(p=0.005)$ and respondents not holding car licences $(<0.01)($ Table 7$)$

\subsection{Theoretical variables}

High intentions to use PPE (Mean=6.26) were identified in this sample. Similar high agreement was also found for injunctive subjective norm (Mean=6.32), descriptive subjective norm (Mean=5.32) and risk perception items (Mean=5.41). Moderate positive attitudes (Mean=4.71), anticipated regret (Mean=5.02) and benefits (Mean=5.20) surrounding PPE were found (Table 8). Habit was present in $98.9 \%$ of respondents.

\subsection{Regression analysis}

Except for attitudes surrounding PPE2 (high-visibility wear); all TRA constructs correlated significantly to the outcome in question, and were hence included in subsequent hierarchical multiple regression analysis. TRA constructs explained $37 \%$ of behavioural variance of PPE1 (Table 9), $7 \%$ of PPE2 (Table 10 ), $23 \%$ of Non-PPE1 (Table 11) and 25\% of Non-PPE2 (Table 12). Intentions were significantly predictive in all outcome regressions, contributing $33 \%$ of behavioural variance to PPE1, $5 \%$ to PPE2, $21 \%$ to Non-PPE1 and $22 \%$ to Non-PPE2 (Tables 9-12). 
The addition of significant rider demographics to TRA variables produced an additional $9 \%$ of behavioural variance to PPE1, $1 \%$ to PPE2, $11 \%$ to Non-PPE1 and $4 \%$ to Non-PPE2 (Tables 9-12). Hypothesis 1 is hereby supported as different rider demographics significantly predicted different PPE outcomes.

Extended Theories of Reasoned Action were found to account for more behavioural variance than TRA alone in all four outcomes. Adding significantly correlated constructs to the TRA and rider demographics added $4 \%$ variance for PPE1, 2\% for PPE2, 2\% for Non-PPE1 and 1\% for Non-PPE2 (Tables 9-12). As TPB was not tested following PCA exclusion of perceived behavioural control, hypothesis 2 is not supported. However, an extended TRA did predict greater outcome variability than original TRA variables alone.

Factors significantly associated with motorcycle jacket, trousers and boots use (PPE1) were greater intentions $(p<0.001)$, anticipated regret $(p<0.001)$, perceived benefits of PPE use $(p<0.05)$ and riding 3001-6000 miles per year $(p<0.05$; Table 9). Factors significantly associated with high-visibility wear (PPE2) were greater intentions $(p<0.05)$ and anticipated regret $(p<0.05)$, habit presence $(p<0.05)$ and scooter riding $(p<0.05$; Table 10). Factors significantly associated with non-motorcycle jeans and trainers use (Non-PPE1) were lower intentions $(p<0.001)$ and anticipated regret $(p<0.05)$, being an urban rider $(p<0.02)$, riding 3001-6000 miles per year $(p<0.05)$ and not holding a car licence $(p<0.05$; Table 11). Factors significantly associated with sandals, shorts and no Personal Protective Equipment use (Non-PPE2) were lower intentions $(p<0.001)$ and risk perceptions $(p<0.05)$, being female $(p<0.005)$ and not holding a car licence $(p<0.05 ;$ Table 12). 


\subsection{Content analysis}

Eighty two participants chose to write additional comments related to PPE use $(30.6 \%$ of sample). This respondent sub-set were significantly older $(F(1,267)=$ 4.02, $p<.05)$, owned larger power bikes $(F(1,267)=5.01, p<0.05)$, held lower risk perceptions $(F(1,267)=10.47, p=.001)$, lower anticipated regret $(F(1,264)=4.94$, $p<.05)$, lower DSN $(F(1,266)=10.95, p=.001)$ and more years of riding experience $(F(1,258)=6.70, p=.01)$.

Ten themes emerged from the data, with these clustered into four concepts (Table 13). Diverse attitudes surrounding PPE importance were evident. Some respondents stressed PPE as essential, whereas others de-emphasised its value: alternatively stressing the importance of riding skills in crash prevention. A need for freedom of choice in PPE use was common, whether respondents stressed its importance or not. Deterring high costs and lack of PPE range were frequently mentioned, along with use being highly dependent on riding situations, such as seasonal weather and journey length. 


\section{Discussion}

This study aimed to explore determinants of motorcyclists' PPE use using an extended Theory of Planned Behaviour. To the author's knowledge, it is the first study to investigate this behaviour primarily through theoretical constructs and in UK riders.

The sample majority reported never wearing leather motorcycle suits $(82.6 \%)$ and reported wearing motorcycle jackets, trousers and boots often or always (81.4\%, similar to ACEM, 2004; Christmas et al. 2009). Similarly, the majority of this sample reported not wearing non-safety wear such as jeans and trainers, unlike other previous research (De Rome et al. 2011b). Although these findings seem encouraging, the context of this questionnaire must be considered. Given that mandatory EU motorcycle PPE legislation is being considered (EUROPA, 2010), responding riders may have over-stated their actual use to demonstrate such legislation as unwarranted.

$82.6 \%$ reported never wearing leather suits. With these typically marketed around motorcycle racing, such advertising may not appeal to typical riders in terms of convenience, cost or style (De Rome \& Stanford, 2006). Middling usage was found for high-visibility wear (as in Christmas et al. 2009; Reeder et al. 1996). Belief elicitation showed dubious attitudes towards high-visibility wear benefits, with respondents viewing car-driver awareness as not improved by its use (as in Blackman \& Haworth, 2010). Research has found high-visibility wear to be effective in crash prevention (Lin \& Kraus, 2009), yet this does not seem to be reflected in rider experience.

Principal components analysis found PBC and related self-efficacy to not load well onto any predictors of PPE use. Hence contrary to hypothesis 2 , an 
extended Theory of Reasoned Action was subsequently examined. With PBC presumed to be predictive of behaviours not under an individual"s conscious control (Ajzen, 1991); it may be inappropriate in the context of volitional PPE use. Strong agreement with PBC items of $74.3 \%$ and $76.8 \%$ suggests ceiling effects may have prompted a lack of variability explanation (Trafimow et al. 2002). With a lack of PBC effect also evident in previous Australian motorcycle (De Rome et al. 2011b) and skating PPE research (Deroche et al. 2009); it appears adoption may be unrestricted by practical implications. This is in contrast to more impulsive, risky driving behaviours such as drink driving (Parker et al. 1992) and speeding (Elliot, 2010), finding PBC to increase intention explanation.

TRA variables explained most of the total identified variability in all four PPE outcomes. Concurring with meta-analytic findings (Armitage \& Connor, 2001), intentions were the central predictor for all outcomes. With wear physically dependent on possessing PPE, it seems logical that intentions before point-ofpurchase may be key for resultant behaviour. No other TRA variables were significantly predictive of any outcomes. Strong positive and negative attitudes were evident in additional comments, suggesting initial belief elicitation to construct the questionnaire may have omitted key ideas (Fishbein \& Ajzen, 2010). A lack of subjective norm explanation is also evident in motorcycling speeding (Elliot, 2010) and limited PPE research (De Rome et al. 2011b). Although a motorcyclist group identity and social context have been found in previous research (Jamson \& Chorlton, 2009; Tunnicliff et al. 2011), social influences are not associated with PPE use in this sample.

Selected constructs extending the TRA were significantly correlated to outcomes. Anticipated regret was both significantly positively associated with PPE outcomes, and negatively associated with non-PPE outcomes. AR is commonly experienced when individuals are personally responsible for an irreversible 
behaviour (Abraham \& Sheeran, 2003). This appears highly relevant in this context, given that PPE is a personal choice and crash occurrence and injury are irreversible.

Risk perceptions assessing individual vulnerability and PPE effectiveness significantly predicted Non-PPE use only. Common male traits of sensationseeking riding and skill confidence (Finucane et al. 2000b; Wong et al. 2010) may lower risk perceptions, contributing to this lack of PPE effect in a predominantly male sample. Benefits identified in pre-questionnaire belief elicitation were associated with jacket and trousers PPE use; with warmth and safety values predictive as in previous research (Tunnicliff et al. 2011). PPE habit was only associated with uncommonly used high-visibility wear, possibly due to an extremely high ceiling effect of $98.9 \%$ of this sample (Austin \& Brunner, 2003).

Additional demographics were associated with PPE outcomes, supporting hypothesis 1 . Scooter users were significantly associated with increased highvisibility wear, contrary to previous research finding less PPE use compared to motorcyclists (Christmas et al. 2009; De Rome et al. 2011b). With only 10.1\% of respondents identifying themselves as scooter riders, a more diverse population would be required to determine any firm comparisons. Larger PPE uptake in this sample may be indicative of high visibility wear availability for the scooter market (De Rome \& Stanford, 2006), accompanied by more negative motorcyclist views towards its use. Additionally, riding the sample's average mileage per annum of 3001-6000 miles was associated with increased PPE uptake. Previous research has found this mileage as average for UK riders (Sexton et al. 2004), suggesting that the general population riding majority may actually hold high PPE uptake.

Holding a car licence was significantly associated with lower Non-PPE use, 
although reported use was still relatively low. Dual-modal drivers have been found to elicit the safest responses at junctions (Crundall et al. 2012), possibly reflected here in their reduced risky clothing choices. Urban riding was also significantly associated with Non-PPE jeans and trainers use. With rural accidents being 1.5 times more serious (DfT, 2004), non-PPE may not be adopted as a precautionary measure by such riders. Females were significantly associated with sandals, shorts and no PPE use. Although this may be attributable to a small female sample size, content analysis revealed a perceived lack of PPE choice for women. Limited manufactured female PPE seemingly reflects women as minority riders (Roster, 2007), with British males making 7x more motorcycle journeys than women (DfT, 2004).

Although previous PPE prevalence research found younger riders to wear less PPE (Christmas et al. 2009); age was not a significant predictor of use in this study. Responses were positively skewed towards older ages which may have contributed to this absent effect, unlike previous research purposefully focusing on younger, novice riders (De Rome et al. 2011b). Additionally, years of riding experience and motorcycle organisation membership did not significantly predict PPE use. Hence, contrary to previous research (De Rome et al. 2011b; De Rome \& Stanford, 2006), more experience and peer rider contact did not equate to increased PPE use in this sample.

Additional comments provided insightful attitudes towards PPE use, producing new themes not included in the preliminary questionnaire. Despite evidently high usage, many respondents emphasised anger at currently debated EU PPE legalisation (EUROPA, 2010). Commenters stressed the need for freedom of choice in its use, disagreeing with restrictions for motorcycling as a liberated activity (Jamson \& Chorlton, 2009; Roster, 2007). Selected riders also deemphasised PPE use in favour of the preventative and protective value of riding skills (as in Blackman \& Haworth, 2010; Lin \& Kraus, 2009). Comments also 
indicated costs in time, money and convenience as barriers to PPE use (as in Blackman \& Haworth, 2010). Although such points were addressed in the study as suggested by pre-questionnaire belief elicitation, they did not load well onto any factors during principal components analysis and were subsequently dropped. The arising theme of PPE situation-dependency including weather considerations supported our separation of seasonal wear (as in de Rome et al. 2011b). A lack of PPE standard clarity was also identified, suggesting a need for objective advice and consumer education (De Rome et al. 2011a). Although UK PPE advice does exist (Think! 2010), it appears this is not specific or publicised enough to sufficiently inform riders in this sample.

\subsection{Limitations}

Although respondents may indicate safety wear use, it may not be sufficiently protective. With potentially poorly protective second-hand wear easily available (Think! 2010), this research cannot quantify quality of clothing reportedly used. There is an evident need to revise this questionnaire in subsequent research. Various attitudes indicated during pre-questionnaire belief elicitation did not attain suitable results for post-PCA analysis, despite being commonly mentioned in later comments. Accordingly, face validity confirmation by a target-population pilot group may have assisted with questionnaire and construct refinement (Fishbein \& Ajzen, 2010). Also, selected constructs such as PBC were measured with minimal items to reduce questionnaire length, potentially contributing to their exclusion in later analysis (Field, 2009). The use of participant self-sampling via online motorcycle forums may have attracted riders with strong views on the topic (Wantland et al. 2004). Inclusion of an arguably passionate motorcycling community may have contributed to skewed results towards PPE use. Findings cannot be generalised to the wider population due to heterogeneous demographics and a relatively modest sample size. However, the use of an online questionnaire method enabled reach of a diverse sample population for this exploratory research (Wright, 2005). 


\subsection{Conclusions}

This preliminary research in UK riders found encouragingly high levels of PPE use, identifying explanatory theoretical variables and a disapproval of related legislation proposals. The TPB concept of PBC was removed following factor analysis. Subsequent extended Theories of Reasoned Action explained greater behavioural variance than the traditional theory alone, suggesting the importance of additional factors. Selected demographics including being female, not holding a car licence and urban riding were only significantly associated with increased non-PPE wear.

Although providing a provisional research basis, confirmatory studies should now be performed to provide larger-scale evidence for future targeted uptake interventions. Qualitative research in riders of various demographics would provide more detail into the PPE attitudes and experiences of riders themselves: extending insightful comments found here. Subsequent extensive research using different recruitment techniques will enable behaviour modelling from a wider sample.

Results of this study and future research should be used to tailor available PPE information around the attitudes and concerns of the riding population. By providing more relevant information materials, riders can make more informed choices regarding PPE use and related injury protection. 


\section{References}

Abraham, C., Sheeran, P., 2003. Acting on intentions: The role of anticipated regret. British Journal of Social Psychology 42, 495-511.

ACEM. (Association of European Motorcycle Manufacturers)., 2004. MAIDS indepth study of accidents involving powered two wheelers, Brussels.

Ajzen, I., 1991. The Theory of Planned Behavior. Organizational Behavior and Human Decision Processes 50, 179-211.

Ajzen, I., Fishbein, M., 2005. The influence of attitudes on behavior. In: D. Albarracin, B. T. Johnson, \& M. P. Zanna. (Eds.), Handbook of attitudes and attitude change: Basic principles, pp. 173-221, Lawrence Erlbaum, NJ.

Ali, M., Saeed, M M.S., Ali, M.M., Haidar, N., 2011. Determinants of helmet use behaviour among employed motorcycle riders in Yazd, Iran based on theory of planned behaviour. Injury 42, 864-869.

Armitage, C. J., Conner, M., 2001. Efficacy of the Theory of Planned Behaviour: A meta-analytic review. British Journal of Social Psychology 40, 471499.

Armitage, C. J., Norman, P., Conner, N., 2002. Can the Theory of Planned Behaviour mediate the effects of age, gender and multidimensional health locus of control? British Journal of Health Psychology 7, 299-316.

Austin, P.C., Brunner, L.J., 2003. Type 1 Error Inflation in the Presence of a Ceiling Effect. The American Statistician 57, 91-104.

Blackman, R.A. \& Haworth, N.L., 2010. A qualitative exploration of the attitudes and experiences of moped and scooter riders. In: TRB $89^{\text {th }}$ Annual Meeting, 10-14 January 2010, Washington DC.

Carpenter, C. J., 2010. A meta-analysis of the effectiveness of health belief model variables in predicting behaviour. Health Communication 25, 661-669.

Chan, D.C., Wu, A. M., Hung, E.P., 2010. Invulnerability and the intention to drink and drive: an application of the theory of planned behaviour. Accident Analysis and Prevention 42, 1549-1555.

Christmas, S., Young, D., Cookson, R., Cuerdenm, R., 2009. Passion, performance, practicality: motorcyclists' motivations and attitudes to safety. Department for Transport.

Cialdini, R.B., Kallgren, C.A., Reno, R.R., 1991. A Focus Theory of Normative Conduct: A Theoretical Refinement and Reevaluation of the Role of Norms in Human- Behavior. Advances in Experimental Social Psychology 24, 201-234.

Conner, M., Armitage, C.J., 1998. Extending the Theory of Planned Behavior: A Review and Avenues for Further Research. Journal of Applied Social Psychology 28, 1429-1464.

Conner, M., Lawton, R., Parker, D., Chorlton, K., Manstead, A.S.R., Stradling, S., 2007. Application of the theory of planned behaviour to the prediction of objectively assessed breaking of posted speed limits. British Journal of Psychology 98, 429-453. 
Crundall, D., Crundall, E., Clarke, D., Shahar, A., 2012. Why do car drivers fail to give way to motorcycles at t-junctions? Accident Analysis and Prevention 44, 88-96.

Cundy, T.P., Systermans, B.J., Cundy, W.J., Cundy, P.J., Briggs, N.E., Robinson, J.B., 2010. Helmets for Snow Sports: Prevalence, Trends, Predictors and Attitudes to Use. Journal of Trauma-Injury Infection and Critical Care 69, $1486-1490$

Deroche, T., Stephan, Y., Castanier, C., Brewer, B.W., Le Scanff, C., 2009. Social cognitive determinants of the intention to wear safety gear among adult in- line skaters. Accident Analysis and Prevention 41, 1064-1069.

De Rome, L., Stanford, G., 2006. Motorcycle protective clothing: fashion or function. The 2006 International Motorcycle Safety Conference. Motorcycle Safety Conference. Motorcycle Safety Foundation, Long Beach. Retrieved 3 June 2012 from www.msf-usa.org/imsc/index.html

De Rome, L., Stanford, G., Wood, B., 2004. Survey of motorcyclists and their safety initiatives. Road Safety Research, Policing and Education Conference, Perth. Retrieved 6 June 2012 from http://site.Iderconsulting.com.au/mcycle/de \%20Rome\%20_Survey\%20of\%20mot orcyclists.pdf

De Rome, L., Ivers, R., Fitzharris, M., Du, W., Haworth, N., Heritier, S. et al., 2011a. Motorcycle protective clothing: Protection from injury or just the weather? Accident Analysis and Prevention 43, 1893-1900.

De Rome, L., Ivers, R., Haworth, N., Heritier, S., Du, W., Fitzharris, M., 2011b. Novice riders and the predictors of riding without motorcycle protective clothing. Accident Analysis and Prevention 43, 1095-1103.

DfT (Department for Transport)., 2004. In Depth Study of Motorcycle Accidents. Department for Transport. London

DfT (Department for Transport)., 2009. Reported motorcyclist casualties: KSI number and rate by month of year (indexed), Great Britain, annually since 2009. Retrieved on July 102012 from:

http://www.dft.gov.uk/statistics/tables/veh0387/

DfT (Department for Transport)., 2010. Practical Riding Test Statistics: moped and motorcycle. Retrieved on 10 December 2011 from:

http://assets.dft.gov.uk/publications/dsa-practical-test-statistics-motorcycle/dsa2011-12-motorcycle-pass-rates-national-mod2-gender-month.pdf

DfT (Department for Transport)., 2012. Annual Road Traffic Estimates 2011. Retrieved on 4 August 2012 from:

http://assets.dft.gov.uk/statistics/releases/road-traffic-estimates-2011/roadtraffic- estimates-2011.pdf

Elliot, M. A., 2010. Predicting motorcyclists' intentions to speed: Effects of selected cognitions from the Theory of Planned Behaviour, self-identity and social identity. Accident Analysis and Prevention 42, 718-725.

Elliott, M.A., Armitage, C.J., 2009. Promoting Drivers' Compliance with Speed Limits: Testing an Intervention based on the Theory of Planned Behaviour.

British Journal of Psychology 100, 111-132.

EUROPA, 2010. Road Safety Programme 2011-2020: detailed measures. 
Retrieved 5 August 2012 from: http://europa.eu/rapid/pressReleasesAction.do? reference $=\mathrm{MEMO} / 10 / 343 \&$ format

=HTML\&aged $=0$ \&language $=E N \&$ guilanguage $=e n$

Faul, F., Erdfelder, E., Lang, A.G., Buchner, A., 2007. G*Power 3: A flexible statistical power analysis program for the social, behavioral, and biomedical sciences. Behavior Research Methods 39, 175-191.

Field, A.E., 2009. Discovering Statistics using SPSS, $3^{\text {rd }}$ Edition, Sage

Publications Inc, California

Finucane, M.L., Alhakami, A., Slovic, P., Johnson, S.M., 2000a. The affect heuristic in judgments of risks and benefits. Journal of Behavioral Decision Making 13, 1-17

Finucane, M.L., Slovic, P., Mertz, C.K., Flynn, J., Satterfield, T.A., 2000b. Gender, race and perceived risk: The "white male" effect. Health Risk \& Society 2, 159-172.

Fishbein, M., Ajzen, I., 1975. Belief, attitude, intention, and behavior: An introduction to theory and research, Addison-Wesley, Reading, ML.

Fishbein, M., Ajzen, I., 2010. Predicting and Changing Behavior: The Reasoned Action Approach, Psychology Press, East Sussex.

Fjeldsoe, B.S., Marshall, A.L., Miller, Y.D., 2009. Behavior Change Interventions Delivered by Mobile Telephone Short-Message Service. American Journal of Preventive Medicine 36, 165-173.

Gardner, B., de Bruijn, G.J., Lally, P., 2011. A systematic review and metaanalysis of applications of the Self-Report Habit Index to nutrition and physical activity behaviours. Annals of Behavioral Medicine 42, 174-187.

Germeni, E., Lionis, C., Davou, B., Petridou, E.T.H., 2009. Understanding reasons for non-compliance in motorcycle helmet use among adolescents in Greece. Injury Prevention 15, 19-23.

Graham, J.M., Guthrie, A.C., Thompson, B., 2003. Consequences of not interpreting structure coefficients in published CFA research. A reminder. Structural Equation Modeling 10, 142-153.

Hardy, M.A., 1993. Regression with dummy variables. Sage university paper series on quantitative applications in the social sciences. Sage, Newbury Park, CA.

Hutcheson, G., Sofroniou, N., 1999. The Multivariate Social Scientist. Sage, London.

Jamson, S., Chorlton, K., 2009. The changing nature of motorcycling: Patterns of use and rider characteristics. Transportation Research Part F 12, 335-346.

Joffe, H., Yardley, L., 2003. Content and Thematic Analysis. In D. Marks. \& Yardley, L. (Eds.), Research Methods for Clinical and Health Psychology, pp. 5668. Sage, Padstow.

Kaiser, H.F., 1960. The application of electronic computers to factor analysis. Educational and Psychological Measurement 20, 141-151. 
Kline, P., 1999. The handbook of psychological testing, 2nd Edition, Routledge, London.

Kobbeltvedt, T., Wolff, K., 2009. The Risk-as-feelings hypothesis in a Theoryof-planned behaviour perspective. Judgment and Decision Making 4, 567-586.

Lally, P., Van Jaarsveld, C.H.M., Potts, H.W.W., Wardle, J., 2010. How are habits formed: Modelling habit formation in the real world. European Journal of Social Psychology 40, 998-1009.

Lin, M.R., Kraus, J. F., 2009. A review of risk factors and patterns of motorcycle injuries. Accident Analysis \& Prevention 41, 710-722.

Liu, B.C., Ivers, R., Norton, R., Boufous, S., Blows, S., Lo, S.K., 2008. Helmets for preventing injury in motorcycle riders. Cochrane Database of Systematic Reviews.

Loewenstein, G.F., Weber, E.U., Hsee, C.K., Welch, N., 2001. Risk as feelings. Psychological Bulletin 127, 267-286.

O'Callaghan, F.V., Nausbaum, S., 2006. Predicting bicycle helmet wearing intentions and behavior among adolescents. Journal of Safety Research 37, 425431.

Oppenheim, A.M., 2000. Questionnaire design, interviewing and attitude measurement, $2^{\text {nd }}$ Edition, Continuum International Publishing Group Ltd, London.

Parker, D., Manstead, A.S.R., Stradling, S.G., Reason, J.T., 1992. Intention to Commit Driving Violations: An Application of Theory of Planned Behaviour. Journal of Applied Psychology 77, 94-101.

Reeder, A.I., Chalmers, D.J., Langley, J.D., 1996. The risky and protective motorcycling opinions and behaviours of young on-road motorcyclists in New Zealand. Social Science \& Medicine 42, 1297-1311

Rivis, A., Sheeran, P., 2003. Descriptive norms as an additional predictor in the theory of planned behaviour: A meta-analysis. Current Psychology 22, 218-233.

Rivis, A., Abraham, C., Snook, S., 2011. Understanding young and older male drivers' willingness to drive while intoxicated: The predictive utility of constructs specified by the theory of planned behaviour and the prototype willingness model. British Journal of Health Psychology 16, 445-456.

Ross, T.P., Ross, L.T., Rahman, A., Cataldo, S., 2010. The Bicycle Helmet Attitudes Scale: Using the Health Belief Model to Predict Helmet Use Among Undergraduates. Journal of American College Health 59, 29-36.

Roster, C.A., 2007. "Girl Power" and Participation in Macho Recreation: The Case of Female Harley Riders. Leisure Sciences 29, 443-461.

Rutter, N., Vance, C., 2011. The determinants of bicycle helmet use: Evidence from Germany. Accident Analysis and Prevention 43, 95-100.

Sandberg, T., Connor, M., 2008. Anticipated regret as an additional predictor in the theory of planned behaviour: A meta-analysis. British Journal of Social Psychology 47, 589-606

Schwarzer, R., 1992. Self-Efficacy in the Adoption and Maintenance of Health 
Behaviors: Theoretical Approaches and a new model. In R. Schwarzer (Ed.), Self Efficacy: Thought Control of Action, pp. 218-244, Hemisphere Publishing Corporation, USA.

Sexton, B., Baughan, C., Elliot, M, Maycock, G., 2004. The accident risk of motorcyclists. TRL Report 607, TRL Limited, London.

Stevens, J., 1996. Applied multivariate statistics for the social sciences, 3rd Edition, Lawrence Erlbaum, Mahwah, NJ.

Tabachnick, B.G., Fidell, L.S., 2001. Using multivariate statistics, $4^{\text {th }}$ Edition, Allyn \& Bacon, Boston.

The Secretary of State for the Environment, Transport and the Regions., 1998. The Motor Cycles (Protective Helmets) Regulations 1998. Retrieved on June 16 2012 from: http://www.legislation.gov.uk/uksi/1998/1807/contents/made

Think!, 2010. Essential Guide for Protective Gear for Bikers. Retrieved on July 10 2012 from: http://think.direct.gov.uk/assets/pdf/dg_195215.pdf

Think!, 2011. Motorcycling. Retrieved on November 22011 from: http://think.direct.gov.uk/motorcycles.html

Trafimow, D., Sheeran, P., Conner, M., Finlay, K.A., 2002. Evidence that Perceived Behavioural Control is a Multidimensional Construct: Perceived Control and Perceived Difficulty. British Journal of Social Psychology 41. 101-121.

Tunnicliff, D., Watson, B., White, K.M., Lewis, I., Wishart, D., 2011. The Social Context of Motorcycle Riding and the Key Determinants Influencing Rider Behavior: A Qualitative Investigation. Traffic Injury Prevention 12, 363-376

Verplanken, B., Aarts, H., 1999. Habit, Attitudes and Planned Behaviour: Is Habit an empty constrict or an interesting case of goal-directed automaticity? European Review of Social Psychology 10, 101-134.

Verplanken, B., Orbell, S., 2003. Reflections on past behavior: A self-report index of habit strength. Journal of Applied Social Psychology 33, 1313-1330.

Wantland, D.J., Portillo, C.J. Holzemer, W.L., Slaughter, R., McGhee, E,M., 2004. The effectiveness of Web-based vs. non-Web-based interventions: a meta-analysis of behavioral change outcomes. Journal of Medical Internet Research 6, e40.

Weinstein, N.D., Kwitel, A., Mccaul, K.D., Magnan, R.E., Gerrard, M., Gibbons, F.X., 2007. Risk perceptions: Assessment and relationship to influenza vaccination. Health Psychology 26, 146-151.

Wells, S., Mullin, B., Norton, R., Langley, J., Connor, J., Lay-Yee, R., Jackson, R., 2004. Motorcycle rider conspicuity and crash related injury: case-control study. British Medical Journal 328 (7444), 857.

Wong, J.T., Chung, Y.S., Huang, S.H., 2010. Determinants behind young motorcyclists' risky riding behavior. Accident Analysis and Prevention 42, 275281.

Wright, K.B., 2005. Researching Internet-based populations: Advantages and disadvantages of online survey research, online questionnaire authoring software packages and web survey services. Journal of Computer-Mediated Communication 10, article 11. 
Figure 1. Theory of Reasoned Action; Fishbein and Azjen, 1975

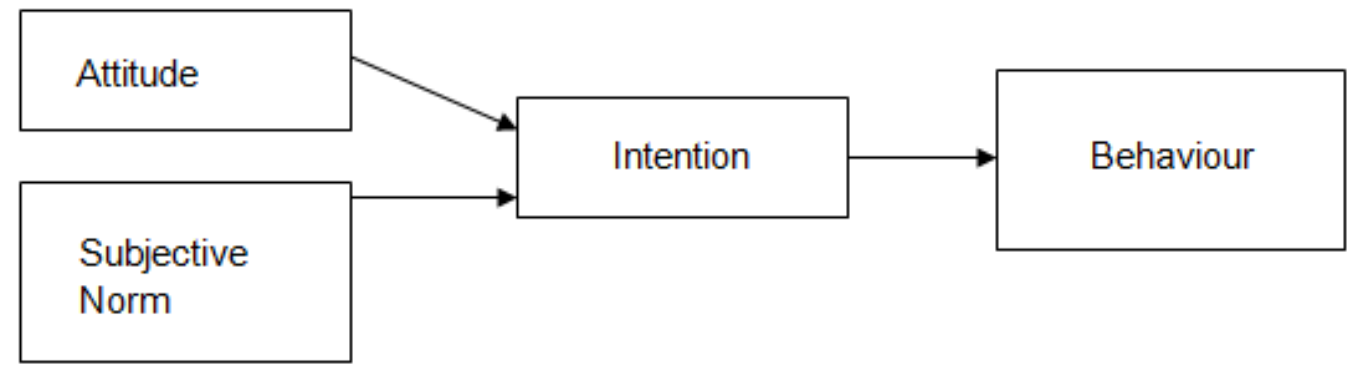

Figure 2. Theory of Planned Behaviour

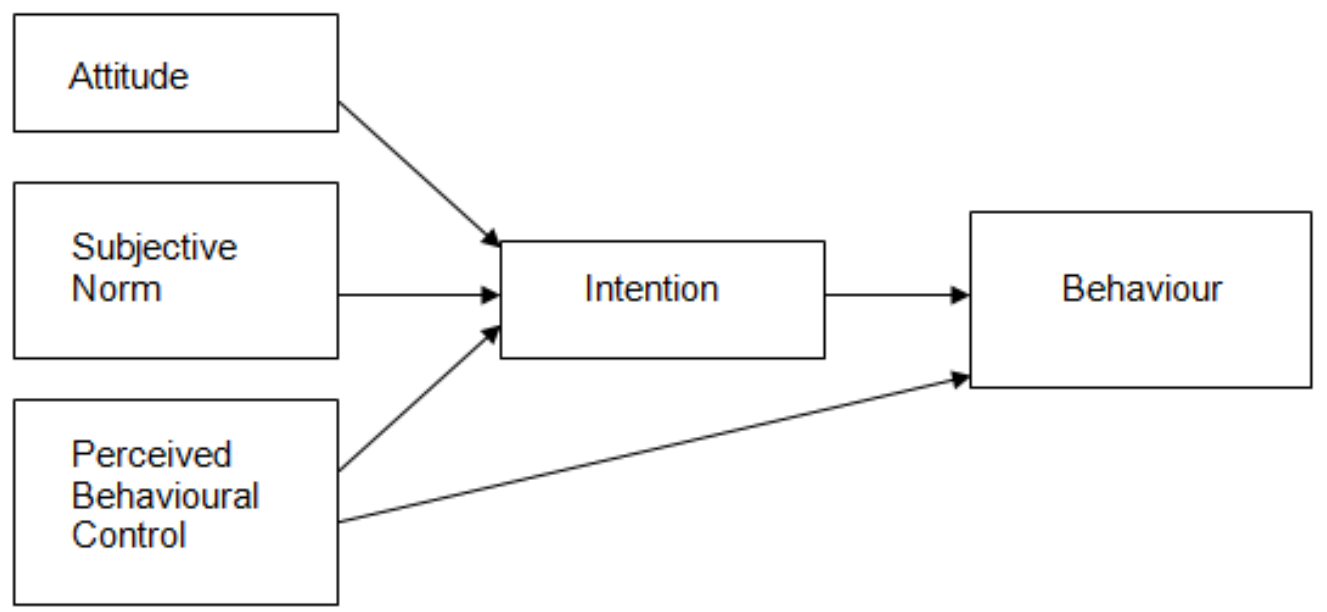

Figure 3. Participant online questionnaire attrition

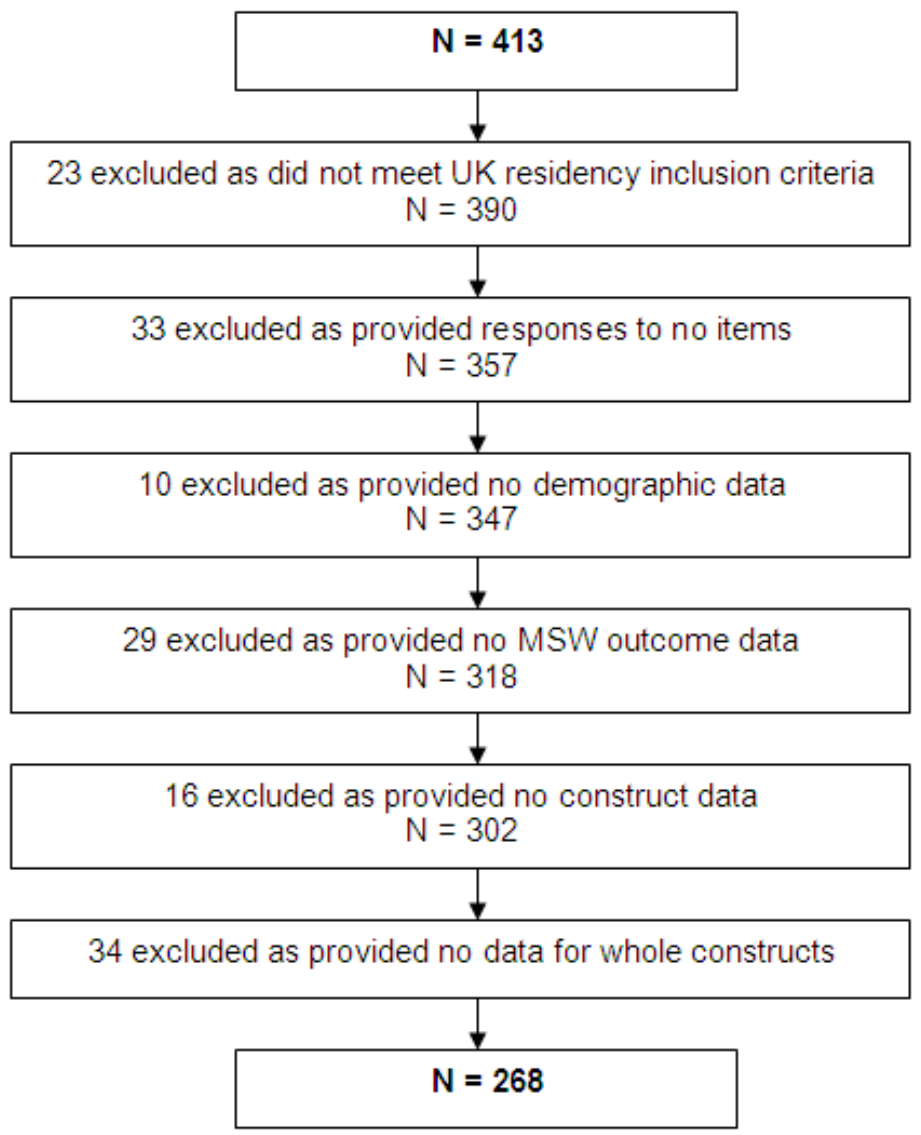


Figure 4. Extended Theory of Reasoned Action (TRA) used following principal components analysis

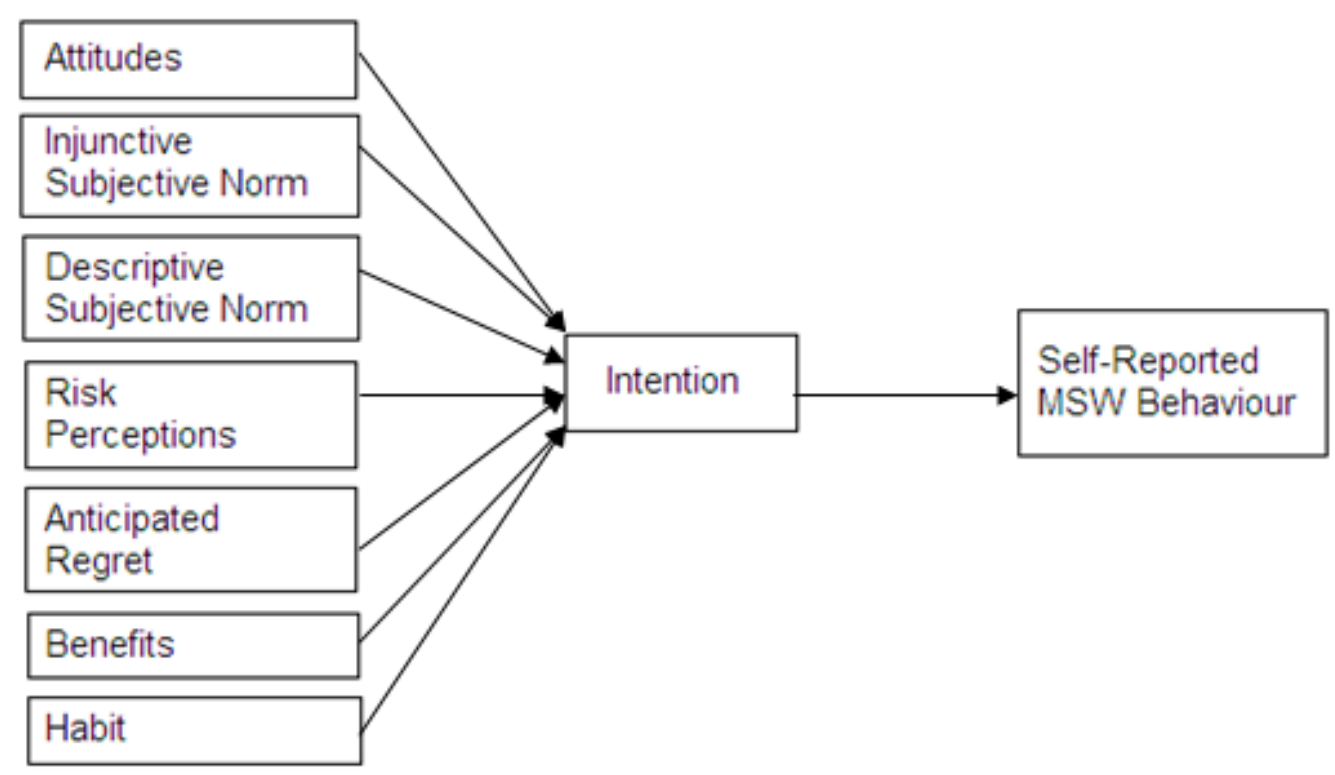


Table 1. Spearman"s correlation coefficients between winter and summer outcomes

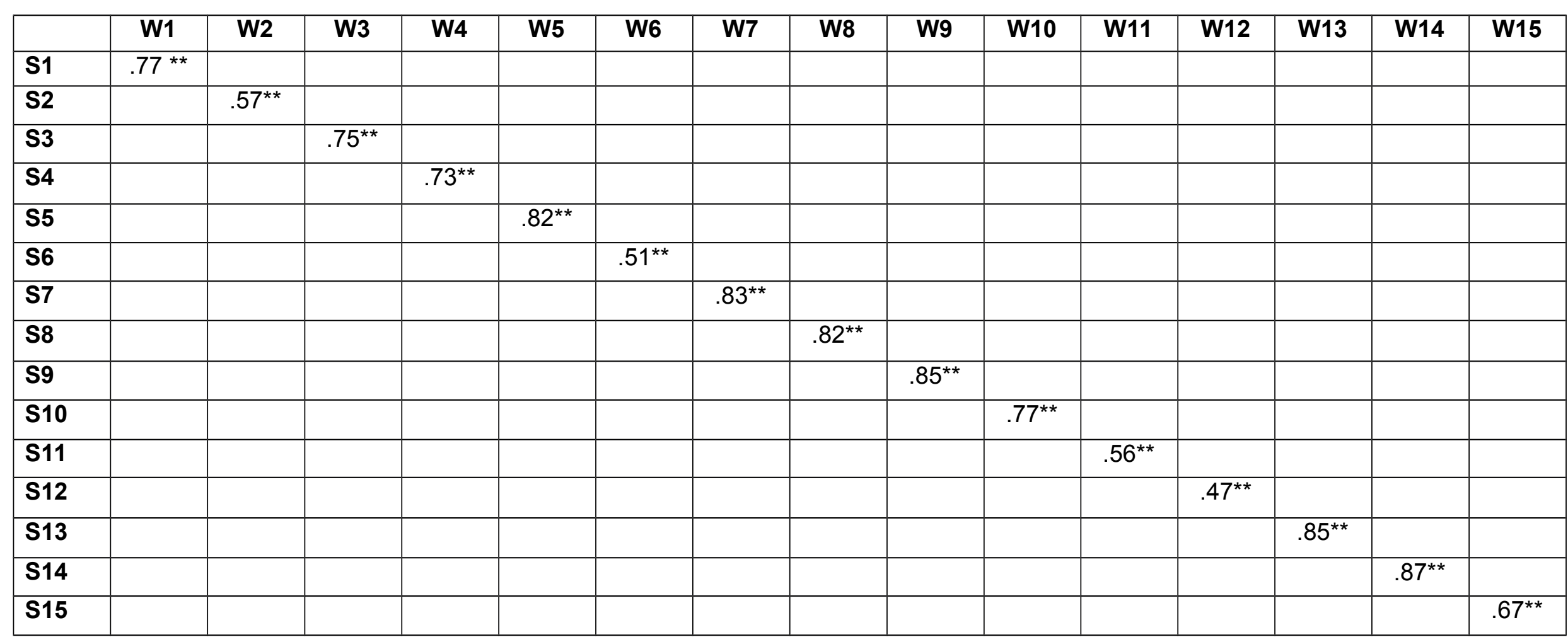

Note: ${ }^{* *} p<0.01 ;$,W" items indicate clothing worn in winter conditions; "S" items indicate clothing worn in summer conditions. 
Table 2. Factors loadings for identified dependent variable items from Pattern and Structure matrices

Item*

$\mathrm{N}$

$\mathrm{N} \quad$ Factors determined through $\mathrm{PCA}^{* *}$

PPE $1 \quad$ PPE2 Non-PPE 1 Non-PPE2

When riding (in winter/summer conditions),

how often do you wear..?

\begin{tabular}{|c|c|c|c|}
\hline A protective jacket (leather or non-leather) (W) & 268 & $\begin{array}{c}0.50 \\
(0.59)\end{array}$ & $\begin{array}{c}0.18 \\
(0.28)\end{array}$ \\
\hline A protective jacket (leather or non-leather) (S) & 268 & $\begin{array}{c}0.69 \\
(0.69)\end{array}$ & $\begin{array}{l}-0.01 \\
(0.18)\end{array}$ \\
\hline Protective trousers (leather or non-leather) (W) & 268 & $\begin{array}{c}0.82 \\
(0.85)\end{array}$ & $\begin{array}{l}0.07 \\
(0.26)\end{array}$ \\
\hline Protective trousers (leather or non-leather) (S) & 268 & $\begin{array}{c}0.87 \\
(0.86)\end{array}$ & $\begin{array}{l}-0.03 \\
(0.18)\end{array}$ \\
\hline Biking boots $(\mathrm{W})$ & 268 & $\begin{array}{c}0.65 \\
(0.63)\end{array}$ & $\begin{array}{c}0.15 \\
(0.06)\end{array}$ \\
\hline Bright/ fluorescent clothing (W) & 268 & $\begin{array}{l}-0.12 \\
(0.11)\end{array}$ & $\begin{array}{c}0.93 \\
(0.89)\end{array}$ \\
\hline Bright/ fluorescent clothing (S) & 268 & $\begin{array}{l}-0.14 \\
(0.09)\end{array}$ & $\begin{array}{c}0.94 \\
(0.90)\end{array}$ \\
\hline Bright/ fluorescent strips on your clothing (W) & 268 & $\begin{array}{c}0.34 \\
\mathbf{( 0 . 4 5 )}\end{array}$ & $\begin{array}{c}0.60 \\
(0.70)\end{array}$ \\
\hline Bright/ fluorescent strips on your clothing (S) & 268 & $\begin{array}{c}0.30 \\
(0.39)\end{array}$ & $\begin{array}{c}0.58 \\
(0.68)\end{array}$ \\
\hline
\end{tabular}

Non-biking jeans (W)

268

$\begin{array}{ll}\mathbf{0 . 8 5} & -0.02 \\ (\mathbf{0 . 8 4}) & (0.35)\end{array}$




\begin{tabular}{|c|c|c|c|}
\hline Non-biking jeans (S) & 268 & $\begin{array}{c}0.89 \\
(0.84)\end{array}$ & $\begin{array}{l}-0.10 \\
(0.28)\end{array}$ \\
\hline Trainers (W) & 268 & $\begin{array}{c}0.72 \\
(0.79)\end{array}$ & $\begin{array}{c}0.15 \\
(\mathbf{0 . 4 6 )}\end{array}$ \\
\hline Trainers (S) & 268 & $\begin{array}{c}0.80 \\
(0.81)\end{array}$ & $\begin{array}{c}0.02 \\
(0.37)\end{array}$ \\
\hline Shorts (W) & 268 & $\begin{array}{l}-0.16 \\
(0.24)\end{array}$ & $\begin{array}{c}0.93 \\
(0.86)\end{array}$ \\
\hline Shorts (S) & 268 & $\begin{array}{c}0.07 \\
(\mathbf{0 . 4 2})\end{array}$ & $\begin{array}{c}0.80 \\
(0.83)\end{array}$ \\
\hline Sandals (W) & 268 & $\begin{array}{l}-0.03 \\
(0.30)\end{array}$ & $\begin{array}{c}0.79 \\
(0.77)\end{array}$ \\
\hline No protective clothing (W) & 268 & $\begin{array}{c}0.18 \\
(\mathbf{0 . 4 7})\end{array}$ & $\begin{array}{c}0.68 \\
(0.76)\end{array}$ \\
\hline No protective clothing (S) & 268 & $\begin{array}{c}0.36 \\
\mathbf{( 0 . 5 5 )}\end{array}$ & $\begin{array}{c}0.42 \\
(0.58)\end{array}$ \\
\hline
\end{tabular}

Note: * Brackets denote whether original items directed winter (W) or summer (S) wear use.

${ }_{* * *}$ Non-bracketed items denote pattern matrix loadings, used to form subsequent factors. Factor loadings over 0.4 are bolded. Bracketed items denote structure matrix loadings. 
Table 3. Correlations between post-PCA outcomes

\begin{tabular}{|l|l|l|l|l|}
\hline & \multicolumn{1}{|c|}{$\begin{array}{c}\text { PPE 1 } \\
\text { (Protective) }\end{array}$} & $\begin{array}{c}\text { PPE 2 } \\
\text { (Preventative) }\end{array}$ & $\begin{array}{c}\text { Non } \\
\text { PPE 1 }\end{array}$ & $\begin{array}{c}\text { Non } \\
\text { PPE 2 }\end{array}$ \\
\hline $\begin{array}{l}\text { PPE 1 } \\
\text { (Protective) }\end{array}$ & - & & & \\
\hline $\begin{array}{l}\text { PPE 2 } \\
\text { (Preventative) }\end{array}$ & $.22^{* *}$ & - & & \\
\hline Non PPE 1 & $-.66^{* *}$ & $-.15^{*}$ & - & \\
\hline Non PPE 2 & $-.48^{* *}$ & $-.16^{* *}$ & $.50^{* *}$ & - \\
\hline
\end{tabular}

Note. ${ }^{*} p<0.05 ;{ }^{* *} p<0.01$. 
Table 4. Factors loadings for all included independent variable items from Pattern and Structure matrices

\begin{tabular}{|c|c|c|c|c|c|c|c|c|c|}
\hline \multirow[t]{2}{*}{ Item* $^{*}$} & \multirow{2}{*}{$\begin{array}{l}\text { Original** } \\
\text { Construct }\end{array}$} & \multirow{2}{*}{$\mathrm{N}$} & \multicolumn{7}{|c|}{ Factors determined through $\mathrm{PCA}^{* * *}$} \\
\hline & & & Intention & Attitude & ISN & DSN & RP & AR & Benefits \\
\hline I intend to wear full PPE on a typical day & Int & 267 & $\begin{array}{c}-0.97 \\
(-0.97)\end{array}$ & $\begin{array}{l}-0.01 \\
(0.30)\end{array}$ & $\begin{array}{c}-0.04 \\
(-0.30)\end{array}$ & & $\begin{array}{l}-0.03 \\
(0.29)\end{array}$ & $\begin{array}{l}-0.03 \\
(0.24)\end{array}$ & $\begin{array}{c}0.01 \\
(0.23)\end{array}$ \\
\hline I intend to wear full PPE on a cold day & Int & 267 & $\begin{array}{l}-0.97 \\
(-0.96)\end{array}$ & $\begin{array}{l}-0.03 \\
(0.27)\end{array}$ & $\begin{array}{l}-0.01 \\
(-0.26)\end{array}$ & & $\begin{array}{l}-0.02 \\
(0.28)\end{array}$ & $\begin{array}{l}-0.03 \\
(0.24)\end{array}$ & $\begin{array}{c}0.03 \\
(0.24)\end{array}$ \\
\hline I intend to wear full PPE on a wet day & Int & 268 & $\begin{array}{c}-0.96 \\
(-0.93)\end{array}$ & $\begin{array}{l}-0.08 \\
(0.22)\end{array}$ & $\begin{array}{c}0.01 \\
(-0.24)\end{array}$ & & $\begin{array}{l}-0.01 \\
(0.28)\end{array}$ & $\begin{array}{l}-0.03 \\
(0.23)\end{array}$ & $\begin{array}{c}0.06 \\
(0.26)\end{array}$ \\
\hline I intend to wear full PPE on a solo ride for leisure & Int & 267 & $\begin{array}{c}-0.95 \\
(-0.95)\end{array}$ & $\begin{array}{c}0.43 \\
(0.34)\end{array}$ & $\begin{array}{c}-0.01 \\
(-0.27)\end{array}$ & & $\begin{array}{c}0.01 \\
(0.31)\end{array}$ & $\begin{array}{l}-0.03 \\
(0.22)\end{array}$ & $\begin{array}{l}-0.03 \\
(0.20)\end{array}$ \\
\hline I intend to wear full PPE on a ride with others & Int & 267 & $\begin{array}{l}-0.97 \\
(-0.95)\end{array}$ & $\begin{array}{c}0.01 \\
(0.29)\end{array}$ & $\begin{array}{c}0.03 \\
(-0.24)\end{array}$ & & $\begin{array}{l}-0.02 \\
(0.29)\end{array}$ & $\begin{array}{l}-0.05 \\
(0.20)\end{array}$ & $\begin{array}{c}0.01 \\
(0.21)\end{array}$ \\
\hline Wearing full PPE whilst riding is unpleasant/ pleasant & Att & 264 & $\begin{array}{c}-0.13 \\
(-0.44)\end{array}$ & $\begin{array}{c}0.68 \\
(0.77)\end{array}$ & $\begin{array}{c}-0.09 \\
(-0.27)\end{array}$ & & $\begin{array}{c}0.06 \\
(0.30)\end{array}$ & $\begin{array}{l}-0.10 \\
(0.12)\end{array}$ & $\begin{array}{c}0.10 \\
(0.25)\end{array}$ \\
\hline Wearing full PPE whilst riding is un-enjoyable/ enjoyable & Att & 266 & $\begin{array}{l}-0.14 \\
(-0.45)\end{array}$ & $\begin{array}{c}0.70 \\
(0.79)\end{array}$ & $\begin{array}{c}-0.15 \\
(-0.32)\end{array}$ & & $\begin{array}{c}0.07 \\
(0.31)\end{array}$ & $\begin{array}{l}-0.11 \\
(0.11)\end{array}$ & $\begin{array}{c}0.04 \\
(0.21)\end{array}$ \\
\hline Wearing full PPE whilst riding is foolish/ wise & Barr & 266 & $\begin{array}{c}0.07 \\
(-0.18)\end{array}$ & $\begin{array}{c}0.75 \\
(0.73)\end{array}$ & $\begin{array}{c}-0.13 \\
(-0.22)\end{array}$ & & $\begin{array}{l}-0.11 \\
(0.11)\end{array}$ & $\begin{array}{c}0.06 \\
(0.14)\end{array}$ & $\begin{array}{c}0.07 \\
(0.15)\end{array}$ \\
\hline $\begin{array}{l}\text { My friends would (strongly disapprove/ strongly approve) } \\
\text { of me wearing full PPE whilst riding (R) }\end{array}$ & ISN & 268 & $\begin{array}{l}-0.14 \\
(-0.40)\end{array}$ & $\begin{array}{c}0.20 \\
(0.35)\end{array}$ & $\begin{array}{c}-0.65 \\
(-0.70)\end{array}$ & & $\begin{array}{l}-0.14 \\
(0.15)\end{array}$ & $\begin{array}{c}0.32 \\
(0.41)\end{array}$ & $\begin{array}{l}-0.01 \\
(0.17)\end{array}$ \\
\hline $\begin{array}{l}\text { My family would (strongly disapprove/ strongly approve) } \\
\text { of me wearing full PPE whilst riding (R) }\end{array}$ & ISN & 268 & $\begin{array}{l}-0.22 \\
(-0.44)\end{array}$ & $\begin{array}{l}-0.06 \\
(0.15)\end{array}$ & $\begin{array}{c}-0.74 \\
(-0.80)\end{array}$ & & $\begin{array}{l}-0.02 \\
(0.23)\end{array}$ & $\begin{array}{c}0.21 \\
(0.29)\end{array}$ & $\begin{array}{l}-0.03 \\
(0.16)\end{array}$ \\
\hline $\begin{array}{l}\text { Most people who are important to me would choose to } \\
\text { wear full PPE whilst riding }\end{array}$ & DSN & 268 & $\begin{array}{l}-0.18 \\
(-0.43)\end{array}$ & $\begin{array}{l}-0.03 \\
(0.19)\end{array}$ & $\begin{array}{l}-0.02 \\
(-0.20)\end{array}$ & $(0.48)$ & $\begin{array}{l}0.44 \\
(0.57)\end{array}$ & $\begin{array}{r}0.33 \\
(\mathbf{0 . 4 8})\end{array}$ & $\begin{array}{l}0.06 \\
(0.31)\end{array}$ \\
\hline Riders I most respect wear full PPE & DSN & 268 & $\begin{array}{l}-0.11 \\
(\mathbf{0 . 4 2})\end{array}$ & $\begin{array}{c}0.01 \\
(0.25)\end{array}$ & $\begin{array}{l}-0.07 \\
(-0.26)\end{array}$ & $(0.55)$ & $\begin{array}{l}0.52 \\
(0.67)\end{array}$ & $\begin{array}{c}0.37 \\
(\mathbf{0 . 5 5})\end{array}$ & $\begin{array}{c}0.12 \\
(0.40)\end{array}$ \\
\hline
\end{tabular}




\begin{tabular}{|c|c|c|c|c|c|c|c|c|c|}
\hline & & & Intention & Attitude & ISN & DSN & $\mathrm{RP}$ & AR & Benefits \\
\hline $\begin{array}{l}\text { Wearing full motorcycle safety clothing whilst riding } \\
\text { would protect me from injury }\end{array}$ & RE & 268 & $\begin{array}{c}-0.07 \\
(-0.28)\end{array}$ & $\begin{array}{l}-0.07 \\
(0.13)\end{array}$ & $\begin{array}{r}0.05 \\
(-0.13)\end{array}$ & & $\begin{array}{l}0.80 \\
(0.78)\end{array}$ & $\begin{array}{l}-0.07 \\
(-0.11)\end{array}$ & $\begin{array}{l}-0.01 \\
(0.23)\end{array}$ \\
\hline $\begin{array}{l}\text { Wearing full motorcycle safety clothing whilst riding } \\
\text { would make me feel safer: }\end{array}$ & RE & 268 & $\begin{array}{r}0.02 \\
(-0.32)\end{array}$ & $\begin{array}{r}0.08 \\
(0.29)\end{array}$ & $\begin{array}{r}-0.22 \\
(-0.39)\end{array}$ & & $\begin{array}{l}0.56 \\
(0.71)\end{array}$ & $\begin{array}{l}0.10 \\
(0.29)\end{array}$ & $\begin{array}{r}0.23 \\
(0.46)\end{array}$ \\
\hline $\begin{array}{l}\text { Without motorcycle safety clothing, I would feel } \\
\text { vulnerable to being seriously injured: } \\
\text { How would you feel if you were injured as a result } \\
\text { of not wearing PPE whilst riding? }\end{array}$ & RAF & 268 & $\begin{array}{l}-0.04 \\
(-0.36)\end{array}$ & $\begin{array}{r}0.03 \\
(0.25)\end{array}$ & $\begin{array}{r}-0.03 \\
(-0.37)\end{array}$ & & $\begin{array}{c}0.52 \\
(0.66)\end{array}$ & $\begin{array}{c}0.33 \\
\mathbf{( 0 . 5 0 )}\end{array}$ & $\begin{array}{c}0.04 \\
(0.33)\end{array}$ \\
\hline Calm/ Worried $(R)$ & AR & 267 & $\begin{array}{c}-0.01 \\
(-0.31)\end{array}$ & $\begin{array}{c}0.04 \\
(0.20)\end{array}$ & $\begin{array}{c}-0.07 \\
(-0.16)\end{array}$ & & $\begin{array}{c}0.04 \\
(0.27)\end{array}$ & $\begin{array}{c}0.86 \\
(0.89)\end{array}$ & $\begin{array}{c}0.06 \\
(0.30)\end{array}$ \\
\hline Settled/ Unsettled (R) & AR & 267 & $\begin{array}{c}0.01 \\
(-0.30)\end{array}$ & $\begin{array}{l}0.08 \\
(0.23)\end{array}$ & $\begin{array}{l}-0.11 \\
(-0.20)\end{array}$ & & $\begin{array}{l}-0.02 \\
(0.24)\end{array}$ & $\begin{array}{l}0.85 \\
(0.88)\end{array}$ & $\begin{array}{l}0.09 \\
(0.32)\end{array}$ \\
\hline Innocent/ Guilty & AR & 266 & $\begin{array}{l}-0.02 \\
(-0.30)\end{array}$ & $\begin{array}{c}0.03 \\
(0.20)\end{array}$ & $\begin{array}{c}0.01 \\
(-0.12)\end{array}$ & & $\begin{array}{c}0.34 \\
(0.49)\end{array}$ & $\begin{array}{c}0.51 \\
(0.62)\end{array}$ & $\begin{array}{l}0.03 \\
(0.27)\end{array}$ \\
\hline Full PPE makes me feel unsafe/ safe & Benef & 266 & $\begin{array}{c}0.02 \\
(-0.20)\end{array}$ & $\begin{array}{c}0.16 \\
(0.33)\end{array}$ & $\begin{array}{c}-0.32 \\
(-0.47)\end{array}$ & & $\begin{array}{l}-0.29 \\
(\mathbf{0 . 5 2})\end{array}$ & $\begin{array}{l}-0.04 \\
(0.16)\end{array}$ & $\begin{array}{l}0.44 \\
(0.59)\end{array}$ \\
\hline Full PPE makes me feel innocent/ guilty $(R)$ & Benef & 264 & $\begin{array}{c}-0.06 \\
(-0.22)\end{array}$ & $\begin{array}{c}0.06 \\
(0.17)\end{array}$ & $\begin{array}{c}-0.06 \\
(-0.18)\end{array}$ & & $\begin{array}{l}-0.06 \\
(0.22)\end{array}$ & $\begin{array}{c}0.03 \\
(0.21)\end{array}$ & $\begin{array}{l}0.80 \\
(0.81)\end{array}$ \\
\hline Full PPE makes me feel cold/ warm & Benef & 267 & $\begin{array}{c}-0.03 \\
(-0.19)\end{array}$ & $\begin{array}{l}-0.04 \\
(0.06)\end{array}$ & $\begin{array}{c}0.16 \\
(0.03)\end{array}$ & & $\begin{array}{l}-0.03 \\
(0.20)\end{array}$ & $\begin{array}{c}0.02 \\
(0.19)\end{array}$ & $\begin{array}{l}0.78 \\
(0.76)\end{array}$ \\
\hline
\end{tabular}

Note: * Items marked $(\mathrm{R})$ have been reversed for analysis.

** Denotes originally designed concepts prior to PCA. „Int" denotes Intention, „Att" denotes attitudes, „Barr" denotes barriers, „RE" denotes response efficacy, „RAF" denotes risk as feelings, „Benef" denotes benefits.

*** Non-bracketed items denote pattern matrix loadings, used to form subsequent factors. Factor loadings over 0.4 are bolded. Bracketed items denote structure matrix loadings. 
Table 5. Internal reliability of post-PCA independent and dependent variables

Variable

Number of items

Cronbach"s a

Independent Variables

Intention

Attitudes

ISN

DSN

Risk Perceptions

AR

Benefits

Habit*

5

3

2

2

3

3

3

12
.98

.79

.80

.71

.74

.84

.64

.95

Dependent Variables

PPE 1 (protective)

PPE 2 (preventative)

Non PPE 1

Non PPE 2

5

4

.83

4

.83

5

.82

Note: * Assessed with Self Report Habit Index (SRHI)

Table 6. Spearman"s correlation coefficients of post-PCA independent variables

\begin{tabular}{|l|l|l|l|l|l|l|l|l|}
\hline & Intention & Attitudes & ISN & DSN & $\begin{array}{c}\text { Risk } \\
\text { Perceptions }\end{array}$ & AR & Benefits & Habit \\
\hline Intention & - & & & & & & & \\
\hline Attitudes & $.31^{* *}$ & - & & & & & & \\
\hline ISN & $.42^{* *}$ & $.34^{* *}$ & - & & & & & \\
\hline DSN & $.42^{* *}$ & $.27^{* *}$ & $.43^{* *}$ & - & & & & \\
\hline $\begin{array}{l}\text { Risk } \\
\text { Perceptions }\end{array}$ & $.36^{* *}$ & $.32^{* *}$ & $.35^{* *}$ & $.65^{* *}$ & - & & & \\
\hline AR & $.28^{* *}$ & $.25^{* *}$ & $.32^{* *}$ & $.58^{* *}$ & $.49^{* *}$ & - & & \\
\hline Benefits & $.21^{* *}$ & $.30^{* *}$ & $.30^{* *}$ & $.47^{* *}$ & $.50^{* *}$ & $.39^{* *}$ & - & \\
\hline Habit & $.47^{* *}$ & $.28^{* *}$ & $.41^{* *}$ & $.46^{* *}$ & $.38^{* *}$ & $.39^{* *}$ & $.22^{* *}$ & - \\
\hline
\end{tabular}

Note: ${ }^{* *} p<0.01$. 
Table 7. Demographics of study sample $(n=268)$ with outcome variable group differences

\begin{tabular}{|c|c|c|c|c|c|}
\hline Categorical Variables & Number (\%) & & Group Diffe & erences & \\
\hline & & PPE1 & PPE2 & Non-PPE1 & Non-PPE2 \\
\hline $\begin{array}{l}\text { Gender } \\
\text { Male } \\
\text { Female }\end{array}$ & $\begin{array}{r}232(86.6 \%) \\
36(13.4 \%)\end{array}$ & $t(266)=-1.25$, n.s & $t(266)=-1.39$, n.s & $U(268)=4260.5, n . s$ & $U(268)=4216$, n.s \\
\hline $\begin{array}{l}\text { Age } \\
17 \text { or younger } \\
18-20 \\
21-29 \\
30-39 \\
40-49 \\
50-59 \\
>60\end{array}$ & $\begin{array}{c}7(2.6 \%) \\
31(11.6 \%) \\
69(25.7 \%) \\
44(16.4 \%) \\
71(26.5 \%) \\
34(12.7 \%) \\
12(4.5 \%)\end{array}$ & $\begin{array}{c}x^{2}(6)=13.29 \\
p<0.05\end{array}$ & $x^{2}(6)=7.28$, n.s & $\begin{array}{c}x^{2}(6)=25.79 \\
p<0.001\end{array}$ & $x^{2}(6)=5.82$, n.s \\
\hline $\begin{array}{l}\text { Motorbike type } \\
\text { Motorcycle } \\
\text { Scooter/ Moped }\end{array}$ & $\begin{array}{r}241(89.9 \%) \\
27(10.1 \%)\end{array}$ & $\begin{array}{c}U(268)=5004.5 \\
p<0.001\end{array}$ & $U(268)=2624$, n.s & $\begin{array}{c}U(268)=2087 \\
p=0.001\end{array}$ & $\begin{array}{c}U(268)=2412.5 \\
p<0.005\end{array}$ \\
\hline $\begin{array}{l}\text { Local area } \\
\text { Town/ City (Urban) } \\
\text { Countryside (Rural) }\end{array}$ & $\begin{array}{r}170(64.9 \%) \\
92(35.1 \%)\end{array}$ & $\mathrm{t}(260)=0.21$, n.s & $t(260)=-0.53, n . s$ & $\begin{array}{c}U(262)=6486.5 \\
p<0.05\end{array}$ & $t(260)=004, n . s$ \\
\hline $\begin{array}{l}\text { Highest Educational Level } \\
\text { No Qualifications } \\
\text { Secondary School } \\
\text { Further Education } \\
\text { University Degree }\end{array}$ & $\begin{aligned} & 5(1.9 \%) \\
& 41(15.7 \%) \\
& 120(46.0 \%) \\
& 95(36.4 \%)\end{aligned}$ & $x^{2}(5)=2.48$, n.s & $x^{2}(5)=6.02$, n.s & $x^{2}(5)=3.72$, n.s & $x^{2}(5)=0.61$, n.s \\
\hline
\end{tabular}




\begin{tabular}{|c|c|c|c|c|c|}
\hline \multirow[t]{2}{*}{ Categorical Variables } & \multirow[t]{2}{*}{ Number (\%) } & \multicolumn{4}{|c|}{ Group Differences } \\
\hline & & PPE1 & PPE2 & Non-PPE1 & Non-PPE2 \\
\hline $\begin{array}{l}\text { Bike Licence } \\
\text { Unrestricted 'A' Licence } \\
\text { Restricted Licence } \\
\text { Other }\end{array}$ & $\begin{array}{c}179(68.6 \%) \\
79(30.3 \%) \\
3(1.1 \%)\end{array}$ & $\begin{array}{c}x^{2}(2)=12.44 \\
p<0.005\end{array}$ & $x^{2}(2)=3.30$, n.s & $\begin{array}{c}x^{2}(2)=14.54 \\
p=0.001\end{array}$ & $x^{2}(2)=3.36$, n.s \\
\hline $\begin{array}{l}\text { Ridden miles per year } \\
\quad 0-3000 \\
3001-6000 \\
6001-10000 \\
>10000\end{array}$ & $\begin{array}{l}88(32.8 \%) \\
82(30.6 \%) \\
46(17.2 \%) \\
42(15.7 \%)\end{array}$ & $x^{2}(5)=10.00$, n.s & $x^{2}(5)=4.19$, n.s & $\begin{array}{c}x^{2}(5)=12.87 \\
p<0.05\end{array}$ & $x^{2}(5)=5.31, n . s$ \\
\hline Motorcycle Organisation Member & $46(17.7 \%)$ & $t(258)=0.50$, n.s & $t(258)=0.56, n . s$ & $t(258)=0.22$, n.s & $\mathrm{t}(258)=0.67, \mathrm{n} . \mathrm{s}$ \\
\hline Car Licence held & $\begin{array}{c}196(74.8 \%) \\
p<0.001\end{array}$ & $U(262)=4264.5$ & $\mathrm{t}(260)=1.23, \mathrm{n} . \mathrm{s}$ & $\begin{array}{c}t(260)=-5.11 \\
p<0.001\end{array}$ & $\begin{array}{c}\mathrm{U}(262)=7403.5 \\
\mathrm{p}<0.05\end{array}$ \\
\hline Motorcycle Accidents in last 3 years & $84(31.3 \%)$ & $\begin{array}{c}t(260)=2.10 \\
p<0.05\end{array}$ & $t(260)=1.20, n . s$ & $t(260)=-1.70$, n.s & $t(260)=0.05, n . s$ \\
\hline
\end{tabular}


Table 8. Descriptive data for variables included in analysis

\begin{tabular}{|c|c|c|c|}
\hline Variable & $N$ & Mean & SD \\
\hline \multicolumn{4}{|l|}{ Independent Variables } \\
\hline $\begin{array}{l}\text { Intentions* } \\
\text { Attitudes* } \\
\text { ISN }^{*} \\
\text { DSN }^{*} \\
\text { Risk Perceptions }^{*} \\
\text { AR* }^{*} \\
\text { Benefits* } \\
\text { Habit** }\end{array}$ & $\begin{array}{l}265 \\
262 \\
267 \\
267 \\
268 \\
265 \\
262 \\
267\end{array}$ & $\begin{array}{l}6.26 \\
4.71 \\
6.32 \\
5.32 \\
5.41 \\
5.02 \\
5.20 \\
1.01\end{array}$ & $\begin{array}{l}1.43 \\
1.25 \\
1.07 \\
1.53 \\
1.39 \\
1.51 \\
0.99 \\
0.11\end{array}$ \\
\hline \multicolumn{4}{|l|}{ Dependent Variables ${ }^{* * *}$} \\
\hline $\begin{array}{l}\text { PPE } 1 \text { (protective) } \\
\text { PPE } 2 \text { (preventative) } \\
\text { Non PPE } 1 \\
\text { Non PPE } 2\end{array}$ & $\begin{array}{l}268 \\
268 \\
268 \\
268\end{array}$ & $\begin{array}{l}4.39 \\
2.62 \\
1.79 \\
1.15\end{array}$ & $\begin{array}{l}0.80 \\
1.22 \\
0.95 \\
0.43\end{array}$ \\
\hline
\end{tabular}

Note: * A score of 1 indicates no agreement with variable, with a score of 7 indicating full agreement

${ }^{* *}$ A score of 1 indicates habit presence as assessed with the Self-Report Habit Index (SRHI) and cut-off score of 21

${ }^{* * *}$ A score of 5 indicates that participants always wear the items, with a score of 1 indicating no wear 
Table 9. Hierarchical multiple regression predicting reported wear of motorcycle jacket, trousers and boots (PPE1)

\begin{tabular}{|c|c|c|c|c|c|c|c|c|}
\hline \multirow[b]{2}{*}{ Step/Predictor } & \multicolumn{2}{|c|}{ Step 1} & \multicolumn{2}{|c|}{ Step 2} & \multicolumn{2}{|c|}{ Step 3} & \multicolumn{2}{|c|}{ Step 4} \\
\hline & B & $\beta$ & B & $\beta$ & $\mathrm{B}$ & $\beta$ & B & $\beta$ \\
\hline 1. Intention & -0.33 & $-0.58^{* *}$ & -0.25 & $-0.44^{* *}$ & -0.25 & $-0.44^{* *}$ & -0.25 & $-0.44^{* *}$ \\
\hline 2. Attitudes & & & -0.08 & $-0.12^{*}$ & -0.03 & -0.04 & -0.04 & -0.06 \\
\hline ISN & & & -0.10 & $-0.13^{*}$ & -0.08 & -0.11 & -0.06 & -0.08 \\
\hline DSN & & & -0.04 & -0.08 & -0.04 & -0.07 & -0.01 & -0.02 \\
\hline 3. Bike type & & & & & -0.67 & $-0.25^{* *}$ & -0.72 & $-0.26^{* *}$ \\
\hline 126-400cc bike size & & & & & 0.01 & 0.01 & -0.07 & -0.02 \\
\hline 401-650cc bike size & & & & & -0.07 & -0.04 & -0.08 & -0.05 \\
\hline Bike licence type & & & & & 0.01 & 0.01 & -0.01 & -0.01 \\
\hline Years riding experience & & & & & 0.01 & 0.03 & 0.01 & 0.01 \\
\hline $3001-6000$ miles ridden $p / a$ & & & & & -0.16 & 0.09 & -0.17 & $-0.10^{*}$ \\
\hline Bike crash in last 3 years & & & & & 0.13 & 0.08 & 0.14 & 0.08 \\
\hline Car licence held & & & & & 0.22 & $0.12^{*}$ & 0.17 & 0.09 \\
\hline 4. Risk Perceptions & & & & & & & 0.01 & 0.02 \\
\hline Anticipated Regret & & & & & & & -0.13 & $-0.24^{\star *}$ \\
\hline Benefits & & & & & & & 0.10 & $0.12^{*}$ \\
\hline Model F & 126 & $.05^{* *}$ & & $.72^{* *}$ & & $94^{* *}$ & & $53^{* *}$ \\
\hline Adjusted $\mathrm{R}^{2}$ & 0. & 33 & & 37 & & 46 & 0. & 50 \\
\hline
\end{tabular}

Note: ${ }^{*} p<0.05 ;{ }^{* *} p<0.001$ 
Table 10. Hierarchical multiple regression predicting reported wear of highvisibility clothing (PPE2)

\begin{tabular}{|c|c|c|c|c|c|c|c|c|}
\hline \multirow[b]{2}{*}{ Step/Predictor } & \multicolumn{2}{|c|}{ Step 1} & \multicolumn{2}{|c|}{ Step 2} & \multicolumn{2}{|c|}{ Step 3} & \multicolumn{2}{|c|}{ Step 4} \\
\hline & B & $\beta$ & B & $\beta$ & B & $\beta$ & $B$ & B \\
\hline 1. Intention & -0.19 & $-0.22^{* * *}$ & -0.12 & $-0.14^{*}$ & -0.13 & $-0.15^{*}$ & -0.13 & $-0.15^{*}$ \\
\hline 2. ISN & & & 0.04 & 0.03 & 0.02 & 0.02 & 0.04 & 0.04 \\
\hline DSN & & & -0.17 & $-0.21^{* *}$ & -0.16 & -0.20 & -0.13 & -0.16 \\
\hline 3. Bike type & & & & & 0.51 & $0.13^{*}$ & 0.49 & $0.12^{*}$ \\
\hline 4. Risk Perceptions & & & & & & & 0.06 & 0.06 \\
\hline Anticipated regret & & & & & & & -0.14 & $-0.18^{*}$ \\
\hline Habit & & & & & & & 1.72 & $0.15^{*}$ \\
\hline Model F & \multicolumn{2}{|c|}{$13.24^{* * *}$} & \multicolumn{2}{|c|}{$7.67^{* * *}$} & \multicolumn{2}{|c|}{$6.91^{* * *}$} & \multicolumn{2}{|c|}{$4.91^{* * *}$} \\
\hline Adjusted $\mathrm{R}^{2}$ & \multicolumn{2}{|c|}{0.05} & \multicolumn{2}{|c|}{0.07} & \multicolumn{2}{|c|}{0.08} & \multicolumn{2}{|c|}{0.10} \\
\hline
\end{tabular}

Note: ${ }^{*} p<0.05 ;{ }^{* *} p<0.01,{ }^{* * *} p<0.001$ 
Table 11. Hierarchical multiple regression predicting reported wear of nonmotorcycle jeans and trainers (Non-PPE1)

\begin{tabular}{|c|c|c|c|c|c|c|c|c|}
\hline \multirow[b]{2}{*}{ Step/Predictor } & \multicolumn{2}{|c|}{ Step 1} & \multicolumn{2}{|c|}{ Step 2} & \multicolumn{2}{|c|}{ Step 3} & \multicolumn{2}{|c|}{ Step 4} \\
\hline & B & $\beta$ & $B$ & $\beta$ & B & $\beta$ & B & $\beta$ \\
\hline 1. Intention & 0.31 & $0.46^{\star * *}$ & 0.24 & $0.36^{* * *}$ & 0.24 & $0.36^{* * *}$ & 0.24 & $0.36^{* * *}$ \\
\hline 2. Attitudes & & & 0.10 & $0.13^{*}$ & 0.06 & 0.08 & 0.05 & 0.07 \\
\hline ISN & & & 0.02 & 0.03 & 0.03 & 0.03 & 0.01 & 0.01 \\
\hline DSN & & & 0.06 & 0.10 & 0.05 & 0.09 & -0.02 & -0.03 \\
\hline 3. Bike type & & & & & 0.23 & 0.07 & 0.27 & 0.09 \\
\hline 126-400cc bike size & & & & & -0.20 & -0.06 & -0.20 & -0.06 \\
\hline $651-1000 \mathrm{cc}$ bike size & & & & & 0.18 & 0.08 & 0.16 & 0.07 \\
\hline Over $1000 \mathrm{cc}$ bike size & & & & & 0.31 & 0.10 & 0.30 & 0.09 \\
\hline Bike licence type & & & & & -0.05 & 0.05 & -0.07 & -0.07 \\
\hline Local area type & & & & & 0.24 & $0.12^{*}$ & 0.26 & $0.13^{*}$ \\
\hline Further Education & & & & & -0.18 & -0.09 & -0.15 & -0.08 \\
\hline $3001-6000$ miles ridden $\mathrm{p} / \mathrm{a}$ & & & & & 0.26 & $0.13^{*}$ & 0.26 & $0.13^{*}$ \\
\hline Bike crash in last 3 years & & & & & 0.01 & 0.01 & -0.02 & -0.01 \\
\hline Car licence & & & & & -0.34 & $-0.16^{* *}$ & -0.31 & $-0.14^{*}$ \\
\hline 4. Risk perceptions & & & & & & & 0.09 & 0.13 \\
\hline Anticipated regret & & & & & & & 0.09 & $0.14^{*}$ \\
\hline Benefits & & & & & & & -0.09 & -0.09 \\
\hline Model F & \multicolumn{2}{|c|}{$67.84^{* * *}$} & \multicolumn{2}{|c|}{$19.58^{* * *}$} & \multicolumn{2}{|c|}{$10.27^{* * *}$} & \multicolumn{2}{|c|}{$9.20^{* * *}$} \\
\hline Adjusted $\mathrm{R}^{2}$ & \multicolumn{2}{|c|}{0.21} & \multicolumn{2}{|c|}{0.23} & \multicolumn{2}{|c|}{0.34} & \multicolumn{2}{|c|}{0.36} \\
\hline
\end{tabular}

Note: ${ }^{*} p<0.05 ;{ }^{* *} p=0.01,{ }^{* *} p<0.001$ 
Table 12. Hierarchical multiple regression predicting reported wear of short, sandals and no Personal Protective Equipment (Non-PPE2)

\begin{tabular}{|c|c|c|c|c|c|c|c|c|}
\hline \multirow[b]{2}{*}{ Step/Predictor } & \multicolumn{2}{|c|}{ Step 1} & \multicolumn{2}{|c|}{ Step 2} & \multicolumn{2}{|c|}{ Step 3} & \multicolumn{2}{|c|}{ Step 4} \\
\hline & B & $\beta$ & $\mathrm{B}$ & $\beta$ & B & $\beta$ & B & $\beta$ \\
\hline 1. Intention & 0.14 & $0.47^{* * *}$ & 0.10 & $0.34^{* \star *}$ & 0.10 & $0.34^{* * *}$ & 0.10 & $0.33^{* * *}$ \\
\hline 2. Attitudes & & & 0.05 & $0.16^{*}$ & 0.04 & $0.13^{*}$ & 0.03 & 0.10 \\
\hline ISN & & & 0.01 & 0.03 & 0.01 & 0.03 & 0.01 & 0.02 \\
\hline DSN & & & 0.03 & 0.12 & 0.03 & 0.10 & -0.01 & -0.02 \\
\hline 3. Gender & & & & & -0.20 & $-0.16^{* *}$ & -0.19 & $-0.15^{\star *}$ \\
\hline Aged 60 years+ & & & & & -0.22 & -0.10 & -0.17 & -0.08 \\
\hline Years riding experience & & & & & -0.01 & -0.03 & -0.01 & -0.12 \\
\hline $3001-6000$ miles ridden $\mathrm{p} / \mathrm{a}$ & & & & & 0.04 & 0.03 & 0.05 & 0.04 \\
\hline Car licence & & & & & -0.10 & -0.10 & -0.12 & $-0.13^{*}$ \\
\hline 4. Risk perceptions & & & & & & & 0.06 & $0.18^{*}$ \\
\hline Anticipated regret & & & & & & & -0.02 & 0.07 \\
\hline Benefits & & & & & & & 0.04 & 0.09 \\
\hline Model F & \multicolumn{2}{|c|}{$70.98^{* * *}$} & \multicolumn{2}{|c|}{$21.97^{* * *}$} & \multicolumn{2}{|c|}{$12.16^{* *}$} & \multicolumn{2}{|c|}{$10.06^{* * *}$} \\
\hline Adjusted $\mathrm{R}^{2}$ & \multicolumn{2}{|c|}{0.22} & \multicolumn{2}{|c|}{0.25} & \multicolumn{2}{|c|}{0.29} & \multicolumn{2}{|c|}{0.30} \\
\hline
\end{tabular}

Note: * $p<0.05 ;{ }^{* *} p<0.01 ;{ }^{* *} p<0.001$ 
Table 13. A count of the main PPE comment themes.

\begin{tabular}{|l|l|}
\hline \multicolumn{2}{|c|}{ "If you have any comments regarding Personal Protective Equipment, please } \\
include these here:"
\end{tabular}


Table 13. Summary of PPE themes in associated concepts.

\begin{tabular}{|c|c|}
\hline Concept & Themes \\
\hline $\begin{array}{l}\text { Anti PPE } \\
\text { legislation }\end{array}$ & $\begin{array}{l}\neg \text { Freedom of Choice } \\
\text { " "Under no circumstances would I accept any } \\
\text { compulsion to wear something I didn"t want to" } \\
\text { " It should always be up to the rider...it is the rider } \\
\text { who pays the price for not wearing suitable gear." } \\
\neg \text { Anti PPE legislation } \\
\circ \text { "..the more the legislators dictate what } \\
\text { motorcyclists wear the less they (riders) will } \\
\text { cooperate" } \\
\text { "If you don"t want to wear it, you shouldn"t } \\
\text { be forced to." } \\
\neg \text { Anti high visibility PPE } \\
\text { "A BIG RED SHINY fire engine with BLUE, } \\
\text { TWOS and BULL HORN can"t be seen by } \\
\text { drivers.. so why would HI VIZ make any } \\
\text { difference?" }\end{array}$ \\
\hline PPE importance & $\begin{array}{l}\neg \text { PPE importance } \\
\circ \text { "It is not choice, it is essential and I wouldn"t } \\
\text { ride without it" } \\
\circ \text { "...it could be the difference between life and } \\
\text { death simple really." }\end{array}$ \\
\hline $\begin{array}{l}\text { Awareness of } \\
\text { realistic PPE } \\
\text { protective value }\end{array}$ & $\begin{array}{c}\neg \text { Injuries being dependent on other road users } \\
\circ \text { "Bikers would be much safer if car drivers were } \\
\text { more aware and used better observation skills." } \\
\neg \text { Riding skill importance } \\
\circ \text { "I prefer better riding skills and to assume all } \\
\text { drivers of cars haven"t seen me" } \\
\text { "Common sense and awareness will do far more } \\
\text { than crash helmets, leather jackets, Kevlar fibres } \\
\text { or armour will ever do for safety" }\end{array}$ \\
\hline PPE use barriers & 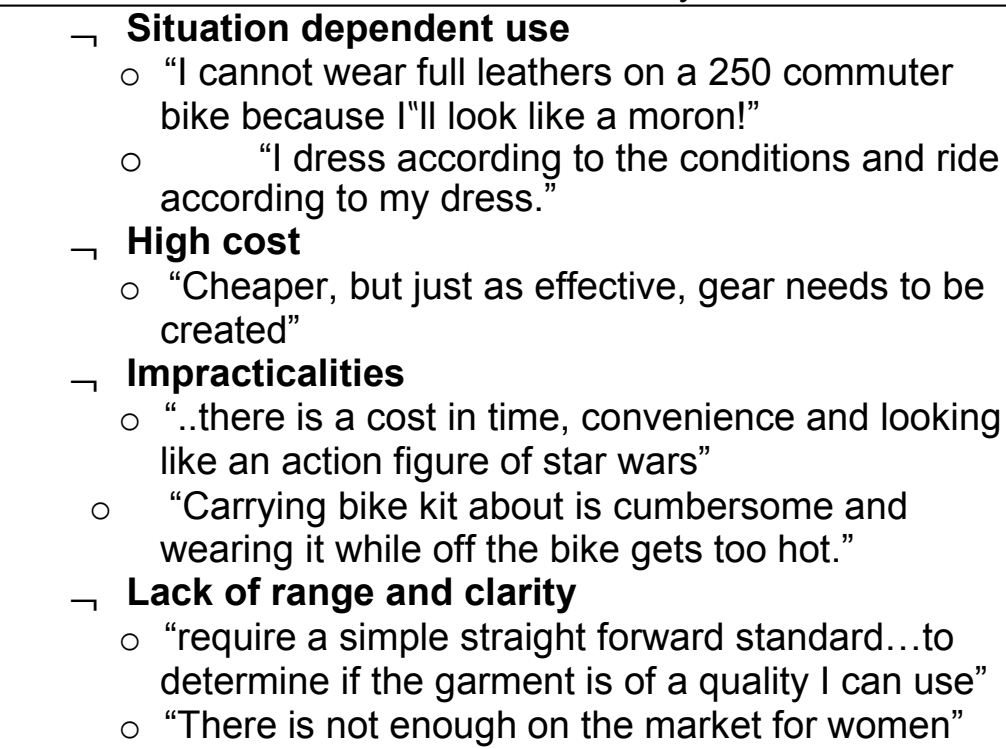 \\
\hline
\end{tabular}

